\title{
İslam Hukukunun Uygulanacak Hukuk Olarak Seçilmesi ve İngiliz Yüksek Mahkemesinin Shamil Bank of Bahrain v. Beximco Kararının Bu Çerçevede Değerlendirilmesi
}

\author{
The Choice of Sharia and An Assessment of English Court of Appeal's \\ Shamil Bank of Bahrain v. Beximco Decision
}

Sibel Özel ${ }^{*}$ (D), Kazım Çınar ${ }^{* *}$ (D)

\section{öz}

Ekonomik alanda İslami devletlerin etkinliğinin artması ile birlikte bu ülkelerin dâhil olduğu uyuşmazlıklarda İslam hukukunun uygulanması talebi artmıştır. Ancak modern hukuk sistemlerinde hukukun kaynağı din değil, yasalardır. Buna karşın özel hukukta yer alan irade serbestisi prensibinin bir sonucu olarak taraflar arasındaki uyuşmazlığa dini kuralların uygulanması mümkündür. Bunun için tarafların geçerli bir hukuk seçimi yapmaları gerekmektedir. Devlet mahkemeleri açısından hukuk seçiminden kastedilen bir devletin hukukunun seçimidir. Bu bakımdan İslam hukukunun uygulanacak hukuk olarak seçilmesi mümkün değildir. Ancak İslam hukukunun anasyonel hukuk kuralları olarak değerlendirilmesi ve sözleşme hükümleri olarak kabul edilmesi imkân dâhilindedir. Yine de hukuk seçimi klozunda sadece İslam hukukuna veya Şeriatın genel prensiplerine atıf yapılması yetersiz kalabilmektedir. Zira İslam hukuku ya da Şeriatın genel prensipleri kavramları bakımından dünya üzerinde yeknesak bir kurallar bütünü ve uygulamanın bulunduğu söylenemez. Buradan hareketle tarafların iradesinin belirsiz ve ilgili hukuk seçiminin geçersiz olduğu sonucuna ulaşlabilmektedir. İngiliz mahkemelerinde görülen Shamil Bank of Bahrain v. Beximco davasında da bu hususlar tartışılmış ve "Yüce Şeriat prensiplerine" yapılan atıf geçersiz kabul edilmiştir.

Anahtar Kelimeler: Hukuk Seçimi, İslam Hukuku, Anasyonel Hukuk Kuralları, Belirlilik, Lex Mercatoria

\section{ABSTRACT}

With the increase in the effectiveness of Islamic states in the economic field, the demand for the implementation of Islamic law in disputes involving these countries has increased. However, in modern legal systems, the source of law is not religion, but laws. On the other hand, as a result of the principle of party autonomy enshrined in private law, it is possible to apply religious rules to disputes between the parties. The parties must make a valid choice of law. For state courts the law chosen by the parties must be a state law. In this respect, it is not possible to choose Islamic law as the law to be applied. However, it is possible for Islamic law to be considered as the non-national rules and be accepted as contractual provisions. However, only referring to Islamic law or the general principles of Shariah in the choice of law clause can be insufficient. For, it cannot be said that there is a single set of rules and practices in the world in terms of the concepts of Islamic law or the general principles of Sharia. In this respect, it is possible to consider the will of the parties as an invalid choice of law since it cannot be revealed. These issues were also discussed in the Shamil Bank of Bahrain v. Beximco case, and the reference to the "Supreme Sharia principles" was deemed invalid.

Keywords: Choice of Law, Islamic Law, Non-National Rules, Certainty, Lex Mercatoria

* Profesör Doktor, Marmara Üniversitesi Hukuk Fakültesi Milletlerarası Özel Hukuk Anabilim Dalı Başkanı

** Doktor, kazim.cinar@marmara.edu.tr

Sorumlu Yazar/Correspondence Author: Sibel Özel

E-posta/E-mail: sibelozel@marmara.edu.tr

Geliş Tarihi/Received: $\quad 27.04 .2021$

Kabul Tarihi/Accepted:

18.05.2021 


\section{GiRiş}

İade serbestisi prensibinin milletlerarası özel hukuktaki en önemli karşılığı olan hukuk seçimi ile hukuki işlem ya da ilişkinin tarafları, aralarındaki ilişkiye uygulanacak hukuku belirleme yetkisine sahip olmaktadır. Taraflara hukuk seçme serbestisi en geniş anlamıyla sözleşmesel ilişkilerde verilmiş, bunun yanında yabancılık unsuru içeren aile, miras, eşya ve sözleşme dışı borç ilişkileri bakımından irade serbestisi lehine gelişmeler olmuştur. Bununla birlikte taraflara verilen hukuk seçme serbestisi sınırsız değildir. Sözleşmeler alanında dahi hukuk seçimi bazı sınırlara tabidir. Bu sınırlardan birisi de taraflarca seçilen hukukun niteliğine ilişkindir.

Seçilen hukukun niteliği ile kastımız seçilen hukukun bir devlet hukuku olması zorunluluğuna ilişkindir. Türkiye dâhil pek çok ülkenin milletlerarası özel hukuk kanunlarında ve AB Tüzüklerinde seçilen hukukun bir devlet hukuku olması gerektiği kabul edilmektedir. Bu durumda anasyonel hukuk kuralları uygulanacak hukuk olarak seçilemez. Taraflar anasyonel hukuk kurallarının seçildiğini belirtse dâhi bu seçim teknik anlamda hukuk seçimi olmadığ1 için öncelikle sözleşmenin tâbi olduğu ulusal hukukun belirlenmesi ve bu hukukun izin verdiği ölçüde anasyonel kuralların uygulanması söz konusu olacaktır. Bir başka ifadeyle anasyonel kuralların seçimi ancak bir sözleşme hükmü olarak işlev görecektir. Buna karşın tahkim ve diğer alternatif uyuşmazlık çözüm yolları bakımından bu husus farklılık arz etmektedir.

Sıkça kullanılan anasyonel hukuk kuralları arasında lex mercatoria, lex sportiva, Viyana Satım Sözleşmesi (CISG), Avrupa Sözleşme Hukuku Prensipleri (EPCL), INCOTERMS bulunmaktadır. İslam ülkelerinin uluslararası ekonomik aktivitelerinin artması ile birlikte -aksi görüş ve uygulamalara karşın - "İslam hukuku" da bu liste arasında yer almaktadır. Nitekim özellikle finans alanında uyuşmazlık çözümünde İslam hukukunun uygulanmasına ilişkin çalışmalar yapılmış ve yapılmaya devam etmektedir. İslam hukuku ile ilgili uyuşmazlıkların çözümü için yapılan çalışmalara Türkiye ve İslam İşbirliği Teşkilatı da katılmış ve İstanbul'da yeni bir tahkim merkezi kurulmuştur. ${ }^{1}$ Merkezin tahkim ve/veya arabuluculuk kuralları henüz belirlenmemiştir ancak İslam ülkeleri arasındaki uyuşmazlıkların çözümü amaçlandığı için İslam hukuku sıkça gündem olacaktır.

İslam hukukunun uygulanacak hukuk olarak seçilebilmesi tartışması yeni bir tartışma değildir. Körfez ülkeleri başta olmak üzere pek çok İslam devleti içinde petrol, doğalgaz, inşaat ve finans sektöründeki şirketler on yıllardır faaliyet göstermekte ve uyuşmazlıklar yaşanmaktadır. Nitekim Körfez ülkelerinde önemli tahkim merkezleri oluşturulmuş, İngiltere başta olmak üzere Batı dünyasının yargı organları İslam hukuku hakkında bazı tartışmalara katılmıştır. Bu çalışmanın

1 İbrahim Özbay / Murat Erdem, 'Bir Kurumsal Tahkim Merkezi Örneği Olarak İslam İşbirliği Teşkilatı Tahkim Merkezi Üzerine Düşünceler' (2020) 2(1), Ankara Sosyal Bilimler Üniversitesi Hukuk Fakültesi Dergisi 12; İsta Blog, 'İslam İșbirliği Teșkilatı Tahkim Merkezi' (2020) < https://ista.org.tr/blog/haberler/islam-isbirligi-teskilati-tahkim-merkezi/> Erişim tarihi 19 Nisan 2021; Yusuf Kumtepe ve Riccardo Loschi, 'Investment Dispute Settlement Body of the Organisation of Islamic Cooperation: A Dead End for Claims under the OIC Investment Agreement?' (2019) Kluwer Arbitration Blog, $<$ http://arbitrationblog.kluwerarbitration.com/2019/12/29/investment-dispute-settlement-body-of-the-organisationof-islamic-cooperation-a-dead-end-for-claims-under-the-oic-investment-agreement/> Erişim tarihi 19 Nisan 2021. 
çatısını oluşturan karar ise İngiliz mahkemeleri tarafından verilen Shamil Bank of Bahrain $v$. Beximco $^{2}$ kararıdır.

Çalışma kapsamında öncelikle anasyonel hukuk kurallarının uygulanacak hukuk olarak seçilip seçilemeyeceği, uyuşmazlığın görüleceği mercii dikkate alınarak ele alınacak ve ardından Shamil Bank of Bahrain v. Beximco kararı irdelenecektir. Son bölümde ise İslam hukukunun uygulanacak hukuk olarak seçilip seçilemeyeceğine ilişkin teorik tartışmalar değerlendirilecektir.

\section{ANASYONEL HUKUK KURALLARININ UYGULANACAK HUKUK OLARAK SEÇILMESI}

Anasyonel hukuk kurallarının uygulanacak hukuk olarak seçilebilmesi hususunda uyuşmazlığın görüldüğü merci önem arz etmekte ve mahkemeler ile tahkim ve diğer alternatif uyuşmazlık çözüm yöntemleri arasında bir ayrım yapılması zaruri görünmektedir.

\section{A. MAHKEMELERDE}

Uygulanacak hukukun seçimine ilişkin ulusal düzenlemelerde genellikle tarafların aralarındaki ilişkiye uygulanmak üzere bir "hukuk" seçebileceği ifade edilmektedir. Örneğin Türk hukukunda Milletlerarası Özel Hukuk ve Usul Hukuku Hakkında Kanun ${ }^{3}$ (MÖHUK) madde 24/1'e göre “sözleşmeden doğan borçilişkileri tarafların açık olarak seçtikleri hukuka tâbidir." 2010 tarihli Yabancılık Unsurlu Özel Hukuk İlişkilerine Uygulanacak Hukuka İlişkin Çin Halk Cumhuriyeti Kanunu madde 41'de "tarafların anlaşmak suretiyle aralarındaki sözleşmelerine uygulanacak hukuku seçebil[ecekleri]" belirtilmiştir. ${ }^{4}$ İsviçre Federal Milletlerarası Özel Hukuk Kanunu madde 116/1'e göre, "sözleşmeler taraflarca seçilen hukuka tabidir." ABD hukukunda Restatement II 'nin 187. Bölümünde taraflarca o konuda özel bir düzenleme yapılmamışsa, "tarafların sözleşmesel haklarına ve borçlarına, taraflarca seçilen ülke hukukunun uygulanacağı” ifade edilmiştir. ${ }^{6}$ Dolayısıyla pek çok ulusal düzenlemede tarafların hukuk seçiminde bulunabileceği ve öncelikle bunun uygulanacağ düzenlenmiştir.

Ulusal hukukların yanı sıra $\mathrm{AB}$ hukukunda üye devletler bakımından doğrudan uygulama alanı bulunan Sözleşmesel Borç İlişkilerine Uygulanacak Hukuk Hakkında Roma I Tüzüğ̈̈7 bakımından tarafların "hukuk" seçebileceği düzenlenmiştir. Tüzüğün 3. maddesinin ilk fikrasına göre, "bir sözleşme taraflarca seçilen hukuka tabidir.” Esasen sadece Roma I Tüzüğü değil, sözleşme dışı alanlarda kanunlar ihtilafına ilişkin diğer bazı Tüzüklerde de benzer düzenlemeler bulunmaktadır.

2 Shamil Bank of Bahrain EC v Beximco Pharmaceuticals Ltd (No.1), [2004] EWCA Civ 19; [2004] 1 W.L.R. 1784; [2004] 4 All E.R. 1072; [2004] 2 All E.R. (Comm) 312; [2004] 2 Lloyd’s Rep. 1; [2004] 1 C.L.C. 216.

3 RG. 12.12.2007, S. 26728.

4 Kanunun İngilizce metni için <http://conflictoflaws.net/News/2011/01/PIL-China.pdf> Erişim tarihi 11 Mart 2021.

5 Kanunun Almanca orijinal metni için <https://www.fedlex.admin.ch/eli/cc/1988/1776_1776_1776/de> Erişim tarihi 11 Mart 2021.

6 Restatement II'nin ilgili bölümü için <http://www.kentlaw.edu/perritt/conflicts/rest187.html> Erişim tarihi 11 Mart 2021.

7 Regulation (EC) No 593/2008 of the European Parliament and of the Council of 17 June 2008 on the law applicable to contractual obligations (Rome I) <https://eur-lex.europa.eu/legal-content/en/ALL/?uri=CELEX:32008R0593> Erişim tarihi 11 Mart 2021. 
Örneğin Sözleşme Dışı Borç İlişkilerine Uygulanacak Hukuk Hakkında Roma II Tüzüğü madde 14’te belirli şartlar altında tarafların "hukuk" seçebileceği ifade edilmiştir.

Ulusal kanunlar, kanunların çıkarıldığı devletlerin; Roma Tüzükleri de ilgili Avrupa Birliği (AB) üye devletlerinin mahkemelerini bağlamaktadır. Yukarıda belirtildiği üzere taraflarca seçilen "hukuk"un uygulanacağına ilişkin hükümlerden hareketle seçilen hukukun bir ülke hukuku olması gerektiği görüşü genel kabul görmektedir. ${ }^{9}$ Dolayısıyla uluslararası ticari örf adet hukuku (lex mercatoria $)^{10}$, uluslararası spor hukuku kuralları (lex sportiva), ${ }^{11}$ UNIDROIT Prensipleri, ${ }^{12}$ Viyana Satım Sözleşmesi(CISG), ${ }^{13}$ Avrupa Sözleşme Hukuku Prensipleri, INCOTERMS gibi ulusal hukuk kavramına girmeyen kuralların seçimi, hukuk seçimi yerine geçmemektedir.

8 Regulation (EC) No 864/2007 of the European Parliament and of the Council of 11 July 2007 on the law applicable to noncontractual obligations (Rome II) <https://eur-lex.europa.eu/legal-content/EN/TXT/?uri=CELEX\%3A32007R0864> Erişim tarihi 11 Mart 2021.

9 Sibel Özel, Milletlerarası Ticari Tahkimde Kanunlar İhtilafı Meseleleri (Legal 2008) 128; Cemal Şanlı, Emre Esen ve İnci Ataman Figanmeşe, Milletlerarası Özel Hukuk (8. Baskı, Beta 2020) 294; Aysel Çelikel ve Bahadır Erdem, Milletlerarası Özel Hukuk (16. Bası, Beta 2020) 397; Vahit Doğan, Milletlerarası Özel Hukuk (6. Bası, Ankara 2020) 405; Berk Demirkol, Milletlerarası Özel Hukuk ve Usul Hukuku Hakkında Kanunun 24. Maddesi Çerçevesinde Sözleşmeye Uygulanacak Hukuk (2. Baskı, Vedat 2014) 147; Sibel Özel, Akreditif ve Hukuki Niteliği (Beta 1991) 76; Tolga Ayoğlu, Uluslararası Ticari Sözleşmelere Uygulanan Genel Prensipler, Maddi Hükümler ve Ticari Adet-Teamüller Olarak Lex Mercatoria (2. Bası, Vedat 2011) 88; A. V. Dicey, J. H. C. Morris and Lawrence, Collins, Dicey, Morris and Collins on the Conflict of Laws (15. Bas1, Sweet\&Maxwell 2012) 1803; Andreas Junius, 'Islamic Finance: Issues Surrounding Islamic Law as a Choice of Law under German Conflict of Laws Principles' (2007) 7(2) Chicago Journal of International Law 546; Christian von Bar and Peter Mankowski, Internalionales Privatrecht (2. Ed, Beck 2003) \$2.86; Jason C. T. Chuah, 'Islamic Principles Governing International Trade Financing Instruments: A Study of the Morabaha in English Law' (2006) 27(1) Northwestern Journal of International Law and Business 142-143.

10 III. Bölümde lex mercatoria üzerinde durulacaktır.

11 Günümüzde serbest zaman ya da sağlık için yapılan aktivitelerin çok ötesinde büyük bir ekonomik sektöre dönüşen sporun etki alanı içerisinde çok sayıda hukuki ilişki bulunmaktadır. Bunların içerisinde profesyonel sporcular ve spor klüpleri arasındaki hizmet sözleşmeleri, ulusal ve/veya uluslararası spor federasyonları arasındaki üyelik ilişkileri, sporcu sözleşmeleri, sponsorluklar, sigorta anlaşmaları, yayın hakkı anlaşmaları bulunmaktadır. Bu çerçevede spor hukukunun ulusal hukuk sistemlerinden bağımsız niteliğini ön plana çıkarmak adına lex sportiva kavramı türetilmiştir. Lex sportiva'nın oluşumunun ana kaynağ 1 Spor Tahkim Mahkemesi(CAS)'nin içtihatlarıdır. Lex sportiva, lex mercatoria gibi, belirli bir hukuk sistemine bağlı olmayan anasyonel hukuk kurallarıdır. Lex sportiva'nın devlet yargısında ve uluslararası tahkimde esasa uygulanacak hukuk olarak değerlendirilmesi için bkz. Hatice Özdemir Kocasakal, Sportif Uyuşmazlıkların Tahkim Yoluyla Çözümü ve Spor Tahkim Mahkemesi (CAS) (Vedat 2013) 38-95; Can Yöney, 'Sözleşmeye Uygulanacak Hukuk Olarak Lex Sportiva' iç Sibel Özel ve Hatice Selin Pürselim Arning (edr), Atipik Sözleşmelere Uygulanacak Hukuk (Oniki Levha 2010) 73 vd; Antoine Duval, 'Lex Sportiva: A Playground for Transnational Law' (2013) 19(6) European Law Journal 822-842; Lorenzo Casini, 'The Making of a Lex Sportiva by the Court of Arbitration for Sport, Lex Sportiva:What is Sports Law?' iç Robert Siekmann and Janwillem Soek (edr) Asser International Sport Law Series (Springer 2012) 149-171.

12 Bahar Ceyda Süral, 'Uluslararası Ticari Sözleşmelere Uygulanacak Hukuk Olarak Unidroit (Özel Hukukun Yeknesaklaştırılması için Uluslararası Enstitü) Prensipleri’ (Doktora Tezi, Dokuz Eylül Üniversitesi 2008) 168 vd.

13 UNCITRAL tarafından hazırlanan 1980 tarihli Birleşmiş Milletler Milletlerarası Mal Satım Sözleşmesi (CISG), bilinen diğer adıyla Viyana Mal Satım Sözleşmesi, uluslararası alanda özel hukukun yeknesaklaştırılması çalışmalarının en başarılı örneklerinden birisidir. Genel olarak işyerleri farklı devletlerde bulunan tacirler arasındaki taşınır mal satım sözleşmesinin düzenlemektedir. Uluslararası ticaretin önemli bir parçası haline gelen Sözleşmeye uluslararası ticaretin yoğun olarak gerçekleştirildiği ülkelerin çoğu (Amerika Birleşik Devletleri, Almanya, Çin, İngiltere Fransa, Japonya, Rusya dâhil) ve toplamda doksan iki ülke taraftır. Bkz. <https://treaties.un.org/Pages/ViewDetails. aspx?src=TREATY\&mtdsg_ no=X-10\&chapter=10\&lang=en $>$ Erişim tarihi 27 Ağustos 2020. Viyana Satım Sözleşmesi, bir devlet hukuku olmadığ için genellikle devlet yargısında uygulanacak hukuk olarak değerlendirilmemekte, fakat Sözleşme kapsamında kalan konularda ilgili hükümler uygulanmaktadır. Buna karşın uluslararası tahkimde Viyana Satım Sözleşmesi sıklıkla 
Bununla birlikte taraflarca seçilen anasyonel hukuk kurallarının hiçbir geçerliliğinin olmadığının ileri sürülmesi, irade serbestisi prensibine aykırılık oluşturacaktır. Gerçekten de günümüzde pek çok ulusal ya da uluslararası nitelikli kurum, çeşitli kurallar dizisi, genel şartlar, sözleşme taslakları, model kanunlar ve benzeri taslak metinler hazırlamaktadır. Ulusal mahkemeler nezdinde bu kuralların "uygulanacak hukuk" kapsamına girmediği kabul edilse de söz konusu anasyonel kuralların sözleşmeye dâhil edilmesi (incorporation by reference) suretiyle uygulanması mümkündür. Anasyonel kurallara atıf yapılmasıyla ilgili kurallar sözleşmenin birer hükmü haline getirilmektedir. Buna bağlı olarak örneğin taraflar uygulanacak hukuk olarak Viyana Satım Sözleşmesỉni ya da lex mercatoria'yı seçerse, bu seçim hukuk seçimi olarak mütalaa edilmeyecek ve uygulanacak hukuk objektif kıstasa göre belirlenecek ve bu hukukun emredici kurallarına aykırı olmayan sözleşme hükümleri uygulanacaktır.

Doktrinde, seçilen hukukun bir devlet hukuku olması zarureti, taraf iradesine ancak bir hukuk düzeninin meşruiyet kazandıracağı ve sözleşmenin bir hukuk düzenine dayanması halinde bağlayıcılık kazanabileceği gerekçesine dayandırılmıştır. ${ }^{14}$ Bunun dışında tarafların mevcut veya ileride çıkabilecek bütün sorunları kapsayacak şekilde bir hukuk seçimi yapamayacakları, sözleşmede düzenlenmeyen konularda uygulanmak üzere bir hukuk sistemine ihtiyaç duyulduğu haklı olarak belirtilmiştir. ${ }^{15}$ Karşılaştırmalı hukukta da hukuk seçimi anlaşması ile seçilebilecek hukukun ancak devlet hukuku olabileceği yönündeki yaklaşım için çeşitli gerekçeler öne sürülmüştür. Örneğin Ancel/ Lequette, bazen emredici/zorlayıcı nitelikte hukuk kurallarının gerekli olduğunu bunu da sadece milli hukukların sağlayabileceğini ifade etmiştir. ${ }^{16}$ Buna karşllık taraflarca seçilebilecek hukukun ulusal hukuk dışında lex mercatoria gibi anasyonel hukuk kuralları olabileceği yönünde görüşler bulunmaktadır. ${ }^{17}$

kullanılmakta, uyuşmazlığın esasına uygulanacak hukuk olarak ele alınmaktadır. Hatta doktrinde bir adım daha ileri gidilerek Viyana Satım Sözleşmesi’nin CISG’nin tahkim anlaşmasının esastan geçerliliğine ilişkin olarak, ve hatta tahkim anlaşmasının kurulması yanında yorumlanması bakımından da CISG’nin uygulanmasının mümkün olabileceğini savunmaktadır. Bu konuda bkz. Can Yöney, 'Viyana Satım Sözleșmesi’nin Tahkim Anlaşmasına Uygulanacak Hukuk Olarak Uygulanabilirliği’ (2019) 2 Galatasaray Üniversitesi Hukuk Fakültesi Dergisi 758-760. Viyana Satım Sözleşmesi’nin tarihi ve uygulama alanı hakkında bkz. Zeynep Derya Tarman, Viyana Satım Antlaşmasııı Uygulamak veya Uygulamamak: CISG'in Uygulama Alanı (Beta 2015) 5 vd; Hatice Özdemir Kocasakal, 'Viyana Konvansiyonu’nun Milletlerarası Özel Hukuk Bakımından Uygulama Alanı' (2013)1 Galatasaray Üniversitesi Hukuk Fakültesi Dergisi 1952; Hüseyin Akif Karaca, 'CISG'in Milletlerarası Uygulama Alanı, İrade Serbestisi ve Bazı Yorum Meseleleri' (2019) 39(1) Milletlerarası Hukuk ve Milletlerarası Özel Hukuk Bülteni 189-215; Peter Winship, 'The Scope of the Vienna Convention on International Sales Contracts' iç Nina M. Galston and Hans Smith (edr), International Sales: The United Nations Convention on Contracts for the International Sale of Goods (New York 1984) 1-53; Yusuf Çalıșkan, Uluslararası Satım Hukukunda Kanunlar İhtilafı Meseleleri (Beta 2014) 124-148; Atakan Adem Selanik, Orkun Bayram ve Işllay Talay Değirmenci, 'Viyana Satım Antlaşması’nın (CISG) Tarihsel Gelişimi ve Uygulama Alanı' (2018) 17(4) Gaziantep Üniversitesi Sosyal Bilimler Dergisi 1353-1367.

14 Cemal Şanlı, Uluslararası Ticari Akitlerin Hazırlanması ve Uyuşmazlıkların Çözüm Yolları (7. Baskı, Beta İstanbul) 49.

15 Şanlı, Ticari Akitler (n 14) 50.

16 Bertrand Ancel and Yves Lequette, Les grands arrets de la jurisprudence française de droit international privê ( 5. Bast, Paris, 2006) 202 (Aktaran: Demirkol, Sözleşmeye Uygulanacak Hukuk (n 9) 147.

17 Peter Nygh, 'The Reasonable Expectations of the Parties As a Guide to the Choice of Law in Contract and in Tort' iç Collected Courses of the Hague Academy of International Law (Brill 1995) 307; Adrian Briggs, 'Decisions of British Courts During 2007: Private International Law’ (2007) 78(1) British Yearbook of International Law 627. 
Roma I Tüzügü̉nün hazırlanması sürecinde devlet hukuku dışında hukuk kurallarının seçilebilmesi hususu tartışılmıştır. Tüzügün Tasarı metninde, uluslararası düzende veya AB'de kabul edilen maddî hukuk ilkeleri ve kurallarının, uygulanacak hukuk olarak seçilebileceği, ancak lex mercatoria ya da uluslararası toplum tarafından yeterince tanınmamış özel kodifikasyonların seçilemeyeceği açıç̧a ifade edilmiştir. ${ }^{18}$ Fakat sonuç olarak hukuk kuralı seçimi reddedilmiştir. ${ }^{19}$ Ancak 2015 tarihli Milletlerarası Ticari Sözleşmelerde Uygulanacak Hukuka İlişkin Lahey Prensipleri’nde ${ }^{20}$ devlet hukuku dışında anasyonel hukuk kurallarının seçilebileceği açıkça düzenlenmiştir (m. 3). Bununla birlikte Prensipler'in 3. maddesine göre, seçilebilecek olan hukuk kurallarının, uluslararası veya bölgesel düzeyde genel kabul görmüş, tarafsız ve dengeli olması gerekmektedir. ${ }^{21}$ Lahey $^{2}$ Prensipleri’nin bu yönüyle de bir yenilik getirdiği ifade edilebilir. ${ }^{22}$

\section{B. TAHKIM YARGILAMASINDA}

Uygulanacak hukuk konusunda anasyonel hukuk kurallarının seçiminin geçerliliği tahkim ve diğer alternatif uyuşmazlık çözüm yöntemlerinde farklılık arz etmektedir. Gerçekten de tahkim ve diğer alternatif uyuşmazlık çözüm yöntemlerinde irade serbestisi prensibi daha ön planda olup bu yollara tarafların rızalarının alınması suretiyle başvurulabilmektedir. ${ }^{23} \mathrm{Bu}$ durumun gözetilmesi ile ulusal ve uluslararası tahkim ve diğer alternatif uyuşmazlık çözüm yöntemlerine ilişkin kurallarda, uyuşmazlığın çözümünde tarafların esasa uygulanacak “hukuk kuralları”nı seçebileceği ifade edilmiştir.

Uyuşmazlığın esasına uygulanmak üzere taraflarca "hukuk kurallarının” seçilebileceği Uluslararası Ticari Tahkime İlişkin UNCITRAL Model Kanun'da ${ }^{24}$ yer almaktadır. Model Kanunun 28. maddesinin ilk fikrasına göre "Hakem Heyeti uyuşmazlığın esasına uygulanmak üzere taraflarca seçilen hukuk

18 Taslak metne aşağıdaki linkten ulaşllabilmektedir: <https://www.europarl.europa.eu/doceo/document/A-6-2007-0450_ EN.html\#title1> Söz konusu hüküm, madde 3'te düzenlenmiştir.

19 Buna karşın Roma I Tüzüğü’nün Önsözünün 13. paragrafında devlet hukuku niteliği taşımayan hukuk kurallarının ve uluslararası konvansiyonların, incorporation yoluyla sözleşmeye dâhil edilmesinin mümkün olduğu vurgulanmıştır.

20 Principles on Choice of Law in International Commercial Contracts, İngilizce metin için <https://www.hcch.net/en/ instruments/conventions/full-text/?cid=135> Erişim tarihi 19 Nisan 2021.

212015 tarihli Lahey Prensiplerinin hukuk kurallarının seçimine ilişkin getirdiği şartlar hakkında bkz. Permanent Bureau of the Hague Conference on Private Internaitonal Law, Commentary on the Principles on Choice of Law in International Commercial Contracts (2015) 40-43; Hüseyin Akif Karaca, 'Uluslararası Ticari Sözleşmelerden Kaynaklı Devlet Mahkemelerindeki Yargılamalarda "Hukuk Kuralları”nın Seçimi: Lahey Prensipleri M. 3’iç Sibel Özel ve Mustafa Erkan (edr), Milletlerarası Özel Hukukta Sözleşmesel Meseleler (Oniki Levha 2018) 124-128 ; Ralf Michaels, 'Non-State Law in the Hague Principles on Choice of Law in International Contracts' iç Kai Purnhagen and Peter Rott (edr) Varieties of European Economic Law and Regulation: Liber Amicorum for Hans Micklitsz (Springer 2014) 59-60; Peter Mankowski, 'Article 3 of the Hague Principles: The Final Breakthrough for the Choice of Non-State Law' (2017) 22(2) Uniform Law Review 373-376.

22 Karaca, 'Hukuk Kuralları' (n 21) 117.

23 Okezie Chukwumerije, Choice of Law in International Commercial Arbitration (Quorum 1994) 2; Cevdet Yavuz, 'Türk Hukukunda Tahkim Sözleşmesi ve Tabi Olduğu Hükümler’ iç II. Uluslararası Özel Hukuk Sempozyumu - Tahkim (TMSF 2009) 133; Cansu Yener Keskin, Milletlerarası Tahkim Anlaşmasının Kurulması ve Etkisi (Oniki Levha 2017) 164; Özel, Tahkim (n 9) 128; Şanl, Ticari Akitler (n 14) 320; Mustafa Erkan, Milletlerarası Tahkimde Yetki Sorunları (Yetkin 2013 ) 39.

24 UNCITRAL Model Kanun'un metni ve şerhi için bkz. United Nations Commission on International Trade Law, UNCITRAL Model Law on International Commercial Arbitration 1985 (With amendments as adopted in 2006) (Vienna, 2008). 
kurallarına göre uyuşmazlğ̆ karara bağlarlar." 1985 tarihli Model Kanunun ardından pek çok ülke Model Kanunu esas alarak ulusal düzeydeki milli ve milletlerarası tahkim kanunlarını çıkartmıştır. Bunlardan birisi olan 4686 sayll Milletlerarası Tahkim Kanunu'nun ${ }^{25}$ 12/C maddesine göre "Hakem veya hakem kurulu, taraflar arasindaki sözleşme hükümlerine ve onların uyuşmazlı̆̆n esasına uygulanmak üzere seçtikleri hukuk kurallarına göre karar verir." Hukuk kurallarının seçilebileceğine ilişkin bu yaklaşım, karşılaştırmalı hukukta da genel kabul görmüştür.

Taraflarca hukuk kurallarının seçimine ilişkin düzenlemeler uluslararası tahkim kurumlarının kuralları içerisinde de yer almaktadır. Örneğin 2021 tarihli revize ICC Tahkim Kurallarının ${ }^{26}$ 21/1. maddesine göre, "taraflar, uyuşmazliğın esasına ilişkin hakem heyeti tarafindan uygulanacak hukuk kuralların belirlemekte özgürdürler. Böyle bir anlaşmanın bulunmaması durumunda, hakem heyeti, uygun olduğunu belirlediği hukuk kurallarım uygular." Viyana Uluslararası Tahkim Merkezinin Tahkim Kuralları içerisinde de "hakem heyeti[nin] uyuşmazlğa taraflarca kararlaştırılan yasal hükümlere veya hukuk kurallarına göre karar verece[ği]" düzenlenmiştir (Madde 27/1). ${ }^{27}$ ISTAC Tahkim Kuralları’nın ${ }^{28} 25$. maddesinde de bu yönde bir düzenleme yapılmış ve "Tek Hakem veya Hakem Kurulu, tarafların uyuşmazlı̆̆ın esasına uygulanmak üzere seçtikleri hukuk kurallarına göre karar verir. Taraflar, uyuşmazlı̆̆ı esasına uygulanacak hukuk kuralların kararlaştırmadıkları takdirde Tek Hakem veya Hakem Kurulu, uygun bulduğu hukuk kurallarını uygular" denilmiştir.

Sonuç olarak mahkemeler nezdinde anasyonel hukuk kurallarının uygulanacak hukuk olarak kullanılması genel olarak kabul görmezken tahkim açısından bu hususa daha esnek yaklaşılmakta ve anasyonel hukuk kurallarının taraflarca seçilebileceği ve bunun hakemlerce uygulanması zarureti kabul edilmektedir. ${ }^{29}$

\section{BEXIMCO V. SHAMIL BANK OF BAHRAIN KARARI ${ }^{30}$}

\section{A. DAVA KONUSU OLAYLAR}

İngiliz mahkemelerinin önüne gelen uyuşmazlık, taraflar arasında yapılan “murabaha sözleşmesi” ile buna bağlı diğer sözleşmelerden kaynaklanmaktadır. Taraflardan Shamil Bank of Bahrain, Bahreyn

25 RG. 05.07.2001, S. 24453.

262021 tarihli Tahkim Kuralları için bkz. <https://iccwbo.org/dispute-resolution-services/arbitration/rules-ofarbitration/> Erişim tarihi 11 Mart 2021.

27 Merkezin 2018 tarihli Tahkim ve Arabuluculuk Kuralları için bkz <https://www.viac.eu/images/documents/vienna_ rules/Wiener_Regeln_2018_Brosch\%C3\%BCre_en_Onlinefassung_Einzelseiten_2._Auflage_20200401.pdf> Erişim tarihi 11 Mart 2021.

28 Merkezin 2016 tarihli Tahkim Kuralları için bkz <https://istac.org.tr/wp-content/uploads/2016/01/\%c4\%b0STANBULTAHK\%c4\%b0M-MERKEZ\%c4\%b0-TAHK\%c4\%b0M-KURALLARI.pdf> Erişim tarihi 21 Mart 2021.

29 Özel, Tahkim (n 9) 142; Turgut Kalpsüz, Türkiye'de Milletlerarası Tahkim (2. Bası, Yetkin 2010) 96; Chukwumerije (n 23) 110; Koray Güven,' Lex Mercatoria Ve Milletlerarası Tahkim' (2014) 34(2) Milletlerarası Özel Hukuk ve Milletlerarası Hukuk Bülteni 27; Nigel Blackaby, Constantine Partasides, Alan Redfern and Martin Hunter, Redfern and Hunter on International Arbitration, (5th Ed, OUP 2009), 215.

30 Shamil Bank of Bahrain EC v Beximco Pharmaceuticals Ltd (No.1), [2004] EWCA Civ 19; [2004] 1 W.L.R. 1784; [2004] 
hukuku çerçevesinde ve Bahreyn Para Kurumu ile Bahreyn Ticaret Bakanlığı’nın verdiği izin ile kurulmuş bir bankadır. Bahreyn Krallı̆̆ı, nüfusunun \%95’i Müslüman olan bir anayasal krallıktır. İslami bankacılığı ulusal bir politika olarak kabul etmesine karşın, İslam hukuku içerisinde yer alan "faiz" dâhil pek çok konu ülkenin ticaret kanunlarında yasaklanmamıştır. ${ }^{31}$ Bilakis Bahreyn Ticaret Kanunu m. 81 hükmü faizi yasal olarak kabul etmiştir. ${ }^{32}$ Buna karşın Shamil Bank of Bahrain, kendisini İslami prensiplere göre işlem yapan bir finansal kuruluş olarak tanıtmaktadır. ${ }^{33}$ Ayrıca genel olarak İslami finans kuruluşlarının faaliyetlerini denetleyen ve bu konuda bir uyumluluk sertifikası veren İslami Finans Kuruluşları Muhasebe ve Denetim Kuruluşu (AAOIFI)'nun ${ }^{34}$ söz konusu raporunun Shamil Bank of Bahrain lehine alındığı ifade edilmiștir. ${ }^{35}$

Uyuşmazlığın davalı tarafında birbiri ile bağlantılı 5 ayrı "kişı”" bulunmaktadır. Bunlar Beximco Pahrmaceuticals Ltd, Bangladesh Export Import Co. Ltd, Beximco Holdings Ltd ile Beximco Pharmaceuticals Ltd şirketi müdürü Ahmad Sohail Fasiuhur Rahman ve Bangladesh Export Import Co.

4 All E.R. 1072; [2004] 2 All E.R. (Comm) 312; [2004] 2 Lloyd's Rep. 1; [2004] 1 C.L.C. 216; (2004) 101(8) L.S.G. 29; Times, February 3, 2004; 2004 WL 62027 (CA (Civ Div) [Temyiz kararl] para. 4. <http://www.bailii.org/ew/cases/ EWCA/Civ/2004/19.html> Erişim tarihi 25 Nisan 2021.

31 Temyiz kararl (n 30) para 4.

32 Söz konusu hüküm şu şekildedir:

"1.Ticari borçların ödenmesinin geciktirilmesi faizi, kanun veya anlaşma aksini öngörmedikçe, bu borçların vadesi geldiğinde tahakkuk edecektir.

2. Alacaklı tarafindan alınacak toplam faiz, faizin hesaplanmasına esas alınan anapara tutarın aşmayacaktır. Bu hüküm, geri ödeme süresi yedi yll geçmeyen borçlar için geçerlidir. Herhangi bir çelişen şart geçersiz ve hükümsüz olacaktır.

3. (2) nci fikra hükümleri, yukarıdaki para birimlerinde yapılan işlemlere ilişkin borçlara uygulanmaz.

4. Alacakl, gecikme faizine ilave edilmek üzere tamamlayıcı tazminat talep etme hakkına sahip olacak ve bu menfaati aşan zararın, borçlunun dolandırıcılı̆̆ veya ağır ihmalinden kaynaklandığını ispat etmesi istenmeyecektir."

Kanunun İngilizce metni için bkz <https://bahrainbusinesslaws.com/laws/Law-of-Commerce> Erişim tarihi 8 Mart 2021.

33 İslami bankacılık uygulamasında genellikle "Danışma(veya Denetim) Kurulu" ve benzeri kurumsal yapılar vasıtasılyla yapılan işlemlerin İslam hukukuna uygunluğu ya da aykırılığı değerlendirilmektedir. Nitekim Shamil Bank of Bahrain şirketinin Kuruluş Sözleşmesi’nde de bu durum anlaşılmaktadır. Kuruluş Sözleşmesinin;

34. maddesinde İslam hukuku, dini hükümler ve İslam ekonomisi alanında uzman ve yetkin olarak tanınan en az 3 kişiden oluşan bir "Dini Denetim Kurulu" oluşturulacağl;

35. maddesinde Dini Denetleme Kurulu’nun, şirketin yatırımlarının ve faaliyetlerinin (ve bağlı ortaklıklarının ve bağlı şirketlerinin faaliyetlerinin) İslami ilke ve hükümlerine uygun olup olmadığını tespit edeceği, şirketin kurulduğu amaçların gerçekleştirilmesini sağlamak için İslami hükümlerin uygulanmasına yönelik tüm önemli kararları alacağı, bu konuda 6 ayda bir rapor sunacağı;

36. maddesinde ise yönetim kurulunun, șirket veya kendi kontrolündeki herhangi bir bağlı ortaklık veya bağlı șirket tarafından herhangi bir başka ticari işlem gerçekleştirmeden önce, tüm yatırımların ve diğer ticari işlemlerin onay için Dini Denetleme Kuruluna gönderilmesini sağlamak için gerekli önlemleri alacağı,

düzenlenmiştir. Kuruluş sözleşmesinde yer alan bu hükümlere mahkeme kararından ulaşılmıştır. Banka 2010 yllında Bahreyn merkezli bir başka yatırım bankası tarafından devralınmıştır.

34 Accounting and Auditing Organization for Islamic Financial Institutions (AAOIFI), 1991 yllinda İslami finans kuruluşları için gerekli olan, fikhi hükümler, muhasebe, denetim ve etik değerler ve kurumsal yönetim alanında İslami kurallara uygun standartlar yayınlamak amacıyla Bahreyn'de kurulmuştur. Kurum, İslami bankacılık standartlarına ilişkin olarak raporlar hazırlamaktadır. Kurum tarafından hazırlanan standartların bir kısmı yakın zamanda Türkçe çevrilmiştir. Söz konusu çeviri için bkz. Faizsiz Finans Standartları, TKBB Yayınları, Erişim: <https://www.izu.edu.tr/ docs/default-source/default-document-library/faizsiz-finans-standartlari.pdf?sfvrsn=968bc0e9_0> Erişim tarihi 25 Kasim 2020.

35 Temyiz kararl (n 30) para 9. 
Ltd müdürü Ahmed Salman Fazlur Rahman'dır. Çalışmamızın bundan sonraki kısmında davalıların hepsi birlikte Beximco adiyla anılacaktır.

Taraflar arasındaki uyuşmazlığın başlangıç noktası 1995 yılında yapılan murabaha anlaşmasıdır. Murabaha, İslami bankacılık sisteminin temelinde olan hukuki işlemdir. İslami bankacılık kapsamında, müşterinin talebi üzerine başlayan süreçte finans kurumu önce müşterinin istediği malı kendi adına peşin olarak satın almakta ve müşteriye vadeli olarak satmaktadır. ${ }^{36}$ Ancak, finans kuruluşu, müşteriyi kendi adına satın alma için temsilci olarak atayabilir ve müşteri, finans kuruluşunun temsilcisi olarak bu tür bir satın alma işlemini gerçekleştirebilir. Peşin alım fiyatı ile müşteriye vadeli satım arasındaki fiyat farkı ise finans kuruluşunun kârı (kâr payı) olarak kabul edilmektedir. ${ }^{37}$ Murabaha sözleşmelerinin şekli ve içeriği değişiklik gösterebilmektedir. ${ }^{38}$

Taraflar arasında yapılan bu sözleşmeden sonra banka, Beximco'ya 15 milyon ABD doları ödeme yapmış, banka lehine de vadeli ödeme planı çıkarılmıştır. ${ }^{39}$ Ancak 1996 yılında taraflar arasında yeni (diğerine ek olarak) bir Murabaha Sözleşmesi yapılmıştır. ${ }^{40}$ Bankaya ödemelerin yapılmaması üzerine1999 yılında borç yapılandırılmış ve şirket yöneticileri bireysel

36 Muhammed Ayub, İslami Finansı Anlamak (Çev: Suna Akten Çürük / Raif Parlakkaya) (İktisat 2017) 235 vd; Atilla Yanpar, İslami Finans - İlkeler, Araçlar ve Kurumlar (Scala 2014) 94. Murâbahanın sahih olması için satım akdinde arananlar yanında şu şartların gerçekleşmiş olması gerekir: a) Önceki satım sözleşmesi sahih olmalıdır. Çünkü murâbaha önceki semen esas alınarak yapılan bir akiddir. Halbuki fâsid akidde Hanefiler'e göre mülkiyet sonucu doğsa da belirlenen fiyat (semen-i müsemmâ) değil mebî̀ kiymeti veya misli dikkate alınır; cumhura göre ise böyle bir akid zaten mülkiyet sonucu doğurmaz. Diğer taraftan Hanefi ve Şâfîller'e göre murâbahaya konu olacak malın satıctya mutlaka satım yoluyla geçmesi gerekmez; hibe ve vasiyet gibi bir yolla mülkiyeti kazanilan bir mal da kıymeti belirlenerek murâbahaya konu yapılabilir. b) Alıs fiyatı taraflarca biliniyor olmalıdır. Alıs fiyatına nelerin dâhil sayılacağı ve bunu etkileyen değişiklikler murâbaha hükümleri arasında geniş bir yer tutar. Alış fiyatı akid meclisi dağılmadan önce müşteriye bildirilmezse murâbaha geçersiz olur. c) Önceki sözleșmede semen aynı cinsten ribevî bir malla değișilmiș olmamalıdır. Ribevî malların kendi cinsleriyle eșit miktarda ve peşin mübadelesi şart kılındiğı için murâbahalı satılması halinde alınan fazlalık kâr değil faiz olur. d) Kâr taraflarca biliniyor olmalıdır. Zira kâr satış bedelinin bir kısmını teşkil etmektedir; satış bedelinin bilinmesi ise bey'in şartlarındandir. Kâr, mâlûm ve muayyen olmak kaydıla gerek misliyyattan gerekse kiyemiyyattan, önceki semenle aynı veya farkh cinsten olabilir. Hanefî, Şâfî̀ ve Hanbelîler'in konuyla ilgili hükü̈mlerinden, kâr hesaplamasında satıcının ilk satıcıya ödediği satım parası yanında maliyete dâhil diğer unsurların da esas alınacağı anlaşılmaktadır (Atıyye Feyyâz, s. 53). Mâlikîler ise maliyete dâhil edilip edilmeyecek unsurları ele alırken bunların kâra yansittlı yansttılmayacağı hususunda bir ayırım yaparlar (aş.bk.). Yukarıda belirtildiği üzere, kârın alı̧ fiyatına veya maliyete oranla belirlenmesini mekruh sayanlar hatta câiz görmeyenler vardır. e) Hanefìler'e göre önceki satım sözleşmesinde semen misliyyattan olmalıdır. Çünkü murâbaha önceki semenin üzerine kâr konarak yapılan bir satımdır. Önceki semen kıyemî mal ise bunun değeri bilinmediğinden murâbahanın semeni de belirsiz kalı. Ancak bu malı mülkiyetinde bulunduran kimseyle oran belirleyerek değil maktû bir kâr ilâvesiyle murâbaha yapılabilir. Şâfî̀ler'e göre bir kimse kıyemî mal karşıllğında satın aldığı bir malı, "Aldığım fiyata veya bana maliyetine satıyorum" diyerek satabilir; ancak kıyemî mal karşıllğında aldığını ve değerini müşteriye bildirmesi gerekir. Bazı Şâfî̀ fakihlerine göre ise malın niteliğini belirtmesi gerekli olmayıp değerini söylemesi yeterlidir. Benzeri görüşler Hanbelîler'de de mevcuttur. Mâlikîler'de ilk akiddeki semenin mislî olup olmamasina ve müşterinin elinde bulunup bulunmamasına göre farkl görüşler ve rivayetler vardır (Mv.F, XXXVI, 320-321). Murabaha hakkında bkz. Türkiye Diyanet Vakf1, İslam Ansiklopedisi, "Murabaha" <https://islamansiklopedisi.org.tr/murabaha> Erişim tarihi 25 Kasım 2020.

Muhammed Nejatullah Siddiqi, Issues in Islamic Banking (IF Londra 1983) 97-98.

38 Yanpar (n 36) 93; Ayub (n 36) 236; Yahia Abdul-Rahman, İslamda Bankacıllk ve Finansman (Çev. Salih Tuğ ve Abdullah Tuğ) (IZÜ 2015) 159-160.

39 Temyiz kararı (n 30) para 15.

40 Temyiz kararı (n 30) para 17. 
olarak garanti vermişlerdir. ${ }^{41} \mathrm{Bu}$ sözleşmeler de 2001 yılında yenilenmiş, son sözleşmeler kapsamında belirli mallar üzerinde Banka lehine mülkiyet hakkı tanınmış, malik konumuna geçen Banka ilgili malların kullanım hakkını davalı şirketlere vermiş, ödemeler konusunda yeni bir takvim belirlenmiştir. ${ }^{42}$ Ödemelerin yapılmaması üzerine Banka, Beximco'ya temerrüt mektubu göndererek tazminat ve ödemeler dâhil toplam yaklaşık 50 milyon dolarlık bir talepte bulunmuştur. Buna bağlı olarak temerrüt mektupları, garantör olarak sözleşmeye dâhil olan yöneticilere de gönderilmiştir. ${ }^{43}$

\section{B. TARAFLARIN IDDIA VE SAVUNMALARI}

Dava içerisinde taraflar pek çok konuda iddia ve savunmalarda bulunmuştur. Ancak İngiliz yargısı tarafından tartışılan asıl konu sözleşmede yer alan uygulanacak hukuk klozunun ve buna bağlı olarak faize ilişkin hüküm içeren sözleşmelerin geçerliliğidir. Taraflar arasındaki sözleşmelerde uygulanacak hukuk klozu şu şekilde inşa edilmiştir: "Yüce Şeriat prensiplerine bağlı olarak bu sözleşme İngiliz hukukuna tabi olacak ve İngiliz hukukuna uygun olarak yorumlanacaktır." 44

İlk derece mahkemesinde davacı Shamil Bank of Bahrain, davalı tarafın, İslam hukukuna ve yürürlükteki yasalara göre geçerli olan sözleşmelerdeki yükümlülüklerini yerine getirmediğini ifade ederek tazminat talebinde bulunmuştur. Davacı Bankanın iddiasını desteklemek üzere aldığı uzman raporunda; genel olarak İslam hukukunun ve özellikle İslami bankacılı̆̆ın kapsamı ve içeriği konusunda ihtilafların olduğu, İslami bankacılığın fiili uygulamasının İslam dünyasında büyük ölçüde farklılık gösterdiği, Pakistan gibi İslami finans sistemlerini uygulamaya koymaya kararlı ve anayasal olarak zorunlu olan ülkelerde bile, devam eden tartışmalar olduğu, murabaha anlaşması dâhil bankacılık işlemlerinin içeriğinin bireysel bankalara kaldığı, hangi finansal işlemlerin İslami olup olmadığı konusunda yasal bir sınırlama yoksa asıl karar mercinin bankalar nezdinde oluşturulan Dini Danışma Kurulu ve benzeri kurullar olduğu ifade edilmiştir. ${ }^{45}$ Bu çerçevede mütalaada, Shamil Bank of Bahrain'in Dini Denetleme Kurulu tarafından uygun bulunan bir işlemin İslam hukukuna uygun olarak değerlendirilmesi gerektiği ileri sürülmüştür. ${ }^{46}$

41 Temyiz kararı (n 30) para 19.

42 Temyiz kararı (n 30) para 19-20.

43 Temyiz kararı (n 30) para 21-23.

44 "Subject to the principles of the Glorious Sharia'a, this Agreement shall be governed by and construed in accordance with the laws of England." Bkz. Temyiz kararı (n 30) para 1.

45 Söz konusu rapor, Londra Üniversitesi Doğu ve Afrika Çalışmaları Okulu (SOAS) İslam ve Ortadoğu Hukuku Merkezi eski başkanı Dr. Martin Lau tarafından hazırlanmıştır. Bkz. Temyiz kararı (n 30) para 29-30. 
Buna karşın davalı Beximco ise, Şeriat hukukunun uygulanması bakımından pek çok farklılığın olduğunu kabul etmiş, ancak faiz yasağı bakımından tartışma olmadığını, Kư’an ${ }^{47}$ ve Sünnet ${ }^{48}$ ile faizin kesin olarak yasaklandığını, eğer sözleşmede faize ilişkin bir hüküm varsa sözleşmenin kesin geçersiz olacağını ileri sürmüştür. ${ }^{49}$ Davalı taraf lehine sunulan uzman görüşünde ${ }^{50}$ ise murabaha ve kira sözleşmelerinin İslam hukukunda kabul edildiği, ancak şeriat ilke ve kurallarına uyması gerektiği, 1999 ve 2001 tarihli yeni sözleşmeleri 1995 ve 1996 tarihli murabaha sözleşmelerinin yeniden yapılandırılması ve buna karşılık vadesi gelen meblağlar üzerinden ek bir meblağ alınmasını içerdiği, bu yönüyle faiz (riba) içerdiği için sözleşmelerin geçersiz olduğu ifade edilmiştir. ${ }^{51}$ Bunun yanı sıra uzman görüşünde, Shamil Bank’’n Dini Denetleme Kurulu'nun finansal işlemlerin Şeriata uygunluğuna ilişkin olarak verilen kararın Şeriat hukuku kapsamında inceleme yapan mahkemeleri ilgilendirmeyeceği ve mahkemelerin kendi bağımsız incelemelerini yapması gerektiğine yer verilmiştir. ${ }^{52}$ Asıl sözleşmelere bağlı olarak verilen kişisel garantilerin de asıl sözleşmenin geçersiz olması sebebiyle söz konusu şirketlerin yöneticilerinin de sorumluluğunun ortadan kalkacağı ileri sürülmüştür. ${ }^{53}$

\section{INGILIZ ILK DERECE MAHKEMESININ KARARI}

İlk derece mahkemesi hâkimi Morison, 1 Ağustos 2003 tarihinde, Shamil Bank of Bahrain lehine kararını vermiş, davacı lehine toplamda 49.7 milyon ABD Doları alacak hakkına hükmetmiştir. İlk derece hâkimi, uygulanacak hukuk klozunun doğru bir şekilde dizayn edilmesi durumunda

47 Bakara Suresinin 275 ilâ 279 . ayetleri faiz yasağına dair temel dayanak olarak gösterilmektedir. İlgili ayetler şu şekildedir: (275) Faiz yiyenler ancak şeytanın çarparak sersemlettiği kimse gibi kalkarlar. Bunun sebebi onların, "Alım satım da ancak faiz gibidir" demeleridir. Halbuki Allah alım satımı helâl, faizi ise haram kılmıştır. Artık kime Allah'tan bir öğüt erişir de faizciliği bırakırsa geçmişte yaptığı kendisine aittir, işi de Allahia kalmıştır. Kim de yine faizciliğe dönerse işte bunlar orada devaml kalmak üzere cehennemliklerdir.

(276) Allah faizi tüketir, sadakaları ise arttırır ve Allah hiçbir inkârcı günahkârı sevmez.

(277) Şüphe yok ki iman edenler, güzel şeyler yapanlar, namaz kılanlar ve zekât verenlerin rableri katında ecirleri vardır; onlara ne korku vardir ne de üzüleceklerdir.

(278) Ey iman edenler! Allah'tan korkun ve gerçekten iman etmiş iseniz faizden kalanı bırakın.

(279) Bunu yapmazsanız Allah ve Resulü tarafindan size bir savaş açıldı̆ını bilin. Eğer tövbe ederseniz, haksızlk etmemek ve hakszzlğg uğramamak üzere ana paranız sizindir.

Bkz. Türkiye Cumhuriyeti Diyanet İşleri Başkanlığı, Kư’an-1 Kerim, erişim: <https://kuran.diyanet.gov.tr/tefsir/sure/2bakara-suresi> Erişim tarihi 1 Aralık 2020.

48 Faiz yasağına dayanak olarak gösterilen bazı hadisler aşağıdaki gibidir: "Cabir'den şöyle nakledildi: Hz. Peygamber (sav), faiz alana/yiyene, veren/yedirene, sözleşmesini yazana, şahitlik yapana lanet etti ve 'Onlarm hepsi suça ortaktır' dedi" (Müslim, Müsakat, 19:106-1598). (Veda hutbesinde) Ribanın her türlüsü kaldırılmıștrr. Anaparanız sizindir. Kimse zulmetmeyecek ve zulme de uğramayacaktır. Allah (cc) kesin bir şekilde faizi haram kılmıştır. Ben faizli işlemlerde anaparadan başkasının alınmamasını, amcam Abbas'in borçlularından alacaklı olduğu faizi iptal ederek başlatıyorum." (Müslim, Hac, 19:147-1218). Hadislere erişim; Ayub (n 36) 49.

49 Shahid Hasan Siddiqui, Islamic Banking, (Pakistan 1994) 9-18; İshak Emin Aktepe, Faiz ve Finansman Hadisleri (Yedirenk 2010) 78 vd; Abdul-Rahman (n 38) 117; Yanpar (n 36) 36; Ayub (n 36) 46-49.

50 Davalı tarafın görüşüne başvurduğu kişi Pakistan Yüksek Mahkemesinin Şeri Temyiz Organı’nın eski başkanı Fazal Khan'dır.

51 Temyiz kararı (n 30) para 33.

52 Temyiz kararı (n 30) para 34.

53 Temyiz kararı (n 30) para 35. 
mahkemenin Şeriat hukukunu uygulaması gerektiğini ancak mevcut durumda Şeriat prensiplerinin hiç dikkate alınmayacağını ifade etmiştir. ${ }^{54}$ Morison’a göre özetle;

a. (O dönemde yürürlükte olan) 1980 tarihli Roma Konvansiyonu m. 3/1’e (şimdi onun yerine Roma I Tüzüğü m. 3) göre seçilen hukukun bir devlet hukuku olması gerekmektedir. Ayrıca taraflar seküler niteliğe sahip olan İngiliz mahkemesinden dini ihtilafları çözmesini beklemiş olamazlar. ${ }^{55}$

b. Uygulanacak hukuk olarak aynı anda iki hukukun seçilmesi mümkün değildir. ${ }^{56}$ Taraflar bir taraftan İngiliz hukukunu seçerken diğer taraftan bunun Şeriat ilkelerine tabi olmasını istemiştir. Şeriat ilkeleri kavramı bir devlet hukuku olmadı̆̆ 1 için uygulanacak hukuk seçimi olarak değerlendirilemez. ${ }^{57}$

c. İslam hukuku uygulanacak hukuk olarak değerlendirilecek olsa bile hukuki ve dini ilkeleri içeren "Yüce Şeriat" kavramı çok fazla belirsizlik barındırmaktadır. ${ }^{58}$ Özellikle şeriat hukukunun hangi ilkelere göre yorumlanacağı veya uygulanacağı konusunda tartışmalar vardır. Pek çok açıdan tartışmalı bir içeriğe sahip olan dini ilkeler bütününün İngiliz mahkemeleri tarafından uygulanmasını beklemek mümkün değildir. ${ }^{59}$

Bu çerçevede hâkim, Shamil Bank’ın iddiası olan, "Yüce Şeriat prensiplerine tabi olarak" ifadesinin Bankanın işlemlerinin Şeriata uygun olduğuna dair kabulden ibaret olduğuna karar vermiştir. ${ }^{60}$ Bir başka deyişle, sözleşmelerin Şeriata aykırı olduğu gerekçesiyle geçersiz olduğu savunmasını reddetmiştir. ${ }^{61}$

\section{INGILIZ YÜKSEK MAHKEMESININ KARARI}

İlk derece mahkemesi kararı üzerine temyize giden davalı tarafın vekili, tek bir uygulanacak hukukun olabileceği, somut olayda bunun İngiliz hukuku olduğunu kabul etmiş, ancak bu durumun Şeriatın genel prensiplerini tamamen dışarıda bırakmadığını, sözleşmenin bir ön şart olarak Şeriat ilkelerine uygun olduğu sürece geçerli olduğunu ileri sürmüştür. ${ }^{62}$ Bir başka deyişle, temyiz eden davalı taraf, Şeriat ilkeleri seçiminin Roma Konvansiyonu çerçevesinde uygulanacak hukuk olarak değil, sözleşme

54 Shamil Bank of Bahrain EC v Beximco Pharmaceuticals Ltd (No.1), [2003] EWHC 2118; [2003] 2 All E.R. (Comm) 849 [ilk derece karari], para 45-46.

55 ilk derece kararı (n 54) para 36, 38.

56 ilk derece kararı (n 54) para 28, 40.

57 ilk derece kararı (n 54) para 24, 35.

58 ilk derece kararı (n 54) para 34.

59 Ilk derece kararı (n 54) para 36.

60 Temyiz kararı (n 30) para 41.

61 "Bir anlamda bu mahkeme kendisine yöneltilen herhangi bir soruyu yantlayacak olsa da, ne kadar zor olursa olsun, tarafların gerçekten bu mahkemeden İlam dini ve ortodoksluk meselelerine girmesini istemeleri imkânsızdır. Banka, uluslararası bankacılık bağlamında Kurul'un kendi İslam hukuku anlayışına bankanın uyumunu sağlamak için kendi dini kuruluna sahiptir. Anlaşmanın yapıldı̆̆ı tarihte veya davadan önce bir şekilde, Şeriat ilkelerinin uygulanmadığı konusunda taraflar itiraz etmemişler ya da endişeli oldukların gösteren bir beyanda bulunmamışlardır. Şeriat hukuku savunması sanırım bir avukatın kurgusudur, ancak geçerli değildir.” illk derece kararı (n 54) para 54-55. 
hükmü olarak değerlendirilmesi gerektiğini belirtmiştir. Bu kapsamda tarafların seçimiyle Lahey Kurallarının $^{63}$ sözleşmeye dâhil edilmiş olduğu yönündeki Nea Agrex SA v. Baltic Shipping CoLtd ${ }^{64}$ kararına ve diğer kararlara atıflar yapılarak ${ }^{65}$ Şeriatın İngiliz mahkemelerinde uygulanabileceği ifade edilmiştir. Son olarak Şeriatın belirsizliği yaklaşımına karşı, somut olay açısından bir belirsizliğin değil, kesinliğin olduğu savunulmuştur. ${ }^{66}$

İngiliz Yüksek Mahkemesi ise Şeriat hukukunun Roma Konvansiyonu bağlamında bir ülke hukuku olmadığını vurguladıktan sonra ${ }^{67}$ sözleşmedeki hukuk seçimi klozu ile genel Şeriat prensiplerinin sözleşmeye dâhil edildiğinin kabul edilemeyeceğini belirtmiştir. Zira Mahkemeye göre, sözleşmeye dâhil etme, ancak tarafların anlaşması ile yabancı bir hukukun, bir uluslararası hukuk metninin ya da kurallar bütününün belirli hükümleri çerçevesinde mümkün olur ve bu hükümler sözleşmenin bir parçası haline gelir. ${ }^{68} \mathrm{Bu}$ durumda, söz konusu kuralın çerçevesi veya etkisi konusunda oluşabilecek belirsizlikler karşısında sözleşmeye dâhil edilen hükümlerin uygulanması ve yorumlanmasında mahkeme, yabancı hukuk uzmanlarından ilgili kuralların kendi yetki alanlarında nasıl uygulandığına dair bilgi isteyebilir. ${ }^{69}$ Fakat "Şeriat hukukunun genel prensipleri” önermesinin belirlilik sağlamadığ 1 kabul edilmiştir.

"Bu durumda Şeriat ilkelerine yapılan genel atıf, çerçevelendirildikleri koşullar bir yana, sözleşmeye dâhil edilmesi amaçlanan şeriat hukukunun ilgili yönlerine hiçbir atıfta bulunmamakta veya bir belirleme yapmamaktadır. Davalıların Şeriatın temel kurallarının bu davada geçerli olduğunu iddia etmeleri açıkça yetersizdir. Bu tür 'temel prensiplere' ne atıfta bulunulmuş ne de tanımlanmıştır. Bu nedenle, “... şeriat ilkelerine” yapılan atıf, genel olarak şeriat kurallarına atıfta bulunmak sonucunu doğurmamaktadır. Bu nedenle, sözleşmeye uygulanacak olan İniliz hukukunun seçimine kaçınılmaz olarak aykırıdır ve uygulanacak hukuk hükmünü çelişkili ve anlamsız kılmaktadır."70

İngiliz hukukunun bankacılık ve finans işlemleri bakımından içtihadi olarak da gelişmiş olduğunu ve tüm dünyada uygulandığını vurgulayan Yüksek Mahkeme, ilk derece mahkemesi kararını onaylayarak, söz konusu uygulanacak hukuk klozunun İngiliz mahkemelerinde Şeriat hukukunun uygulanması yönünde bir anlam taşımayacağını ifade etmiştir. ${ }^{71}$ Bu çerçevede temyiz eden davalının atıf verdiği içtihat hukukunda yer alan Glencore International v. Metro Trading davasında Birleşik Arap Emirlikleri içerisinde yer alan özerk birimlerden birisi olan Füceyre’nin Medeni Kanunu

63 International Convention for the Unification of Certain Rules of Law relating to Bills of Lading (The Hague Rules), Brussels, 1924.

64 Nea Agrex SA v. Baltic Shipping Co Ltd [1976] 1 QB 933(CA).

65 Glencore International AG v Metro Trading International Inc [2001] 1 Lloyds Law Rep 284, para. 113-125; Al-Bassam v Al-Bassam [2002] EWHC 2281 (Ch).

66 Temyiz kararı (n 30) para 45.

67 Temyiz kararı (n 30) para 48.

68 Temyiz kararı (n 30) para 51.

69 Temyiz kararı (n 30) para 51.

70 Temyiz kararı (n 30) para 52.

71 Temyiz kararı (n 30) para 54. 
çerçevesinde uyuşmazlık konusunu hukuki olarak tanımlanmıştır. Al Bassam kararında ise taraflar ölen kişinin ölüm tarihinde ikâmetgah ülkesi olarak Suudi Arabistan hukukunun uygulanmasında mutabık kaldıkları için Şeriat hukuku uygulanmıştır. Davalı temyiz edenin iddiasının aksine bu davalar da seçilen hukukun bir devlet hukuku olması gerektiğini göstermektedir. ${ }^{72}$

Her iki uyuşmazlık tarafının takdim ettiği uzmanların belirttiği üzere, dini ve ahlaki kuralların modern dönemde yeniden ele alınmasında görüş birliği bulunmayan hususlar bulunmaktadır. Bu durumun oluşmasında farklı düşünce okullarının varlığı başlıca etkendir. Faizin yasaklanması konusunda genel bir kabul olsa da bu durum sözleşmeye uygun bir şekilde dâhil edilmemiştir. Bu yüzden sözleşme geçerliliğinin hükümlerinin sadece İngiliz hukukuna göre ele alınması gerekir. Bu durumda da sözleşme geçerli ve davalı temyiz eden taraf davacı Bankaya karşı sorumlu olacaktır. ${ }^{73}$

Garantör konumunda olan Beximco Pharmaceuticals Ltd. şirketi müdürü Mr. Ahmad Sohail Fasiuhur Rahman ve Bangladesh Export Import Co. Ltd müdürü Mr. Ahmed Salman Fazlur Rahman'in sorumluluğu da yukarıdaki açıklamalara bağlı olarak geçerli olacaktır. ${ }^{74}$

\section{UYGULANACAK HUKUK OLARAK ISLAM HUKUKUNUN SEÇILMESI}

\section{A. ISLAM HUKUKUNUN KAPSAMI VE MODERN HUKUK SISTEMLERINDEKI POZISYONU}

Kavramsal olarak İslam hukuku ile fikıh kavramları birbirinin yerine kullanılmaktadır. ${ }^{75}$ Fıkıh ilk olarak "nasslardan çıkarılan hükümler" olarak tanımlansa da alt ayrımları gözetilmeden zamanla İslam hukuku olarak kullanılmaya başlanmıştır. ${ }^{76}$ Ancak hukuk, insanlar arası dış münasabetler ve dünya düzeni ile ilgili iken fıkıh bunlara ek olarak dini vazifeleri ve dünya sonrası ahiret hayatını da ele almaktadır. ${ }^{77}$ Fıkıh içerisinde ibadetler, muamelat ve ukubat kuralları bulunmakta iken zamanla ibadetlere ilişkin hükümler fıkıhtan ayrıştırılmıştır. ${ }^{78}$ İslam hukuku yerine karşılaştırmalı hukukta Şeriat kavramı daha çok tercih edilmektedir. Şeriat, İslam’ın dini, ibadetsel, ahlaki ve hukuki sistemleri dâhil olmak üzere tüm İslam yasalarının adı olarak tanımlanmaktadır. ${ }^{79}$ Ancak modern hukuk sistemleri İslam hukukunun ibadetlere ve ahiret hayatına ilişkin hükümleri ile ilgilenmemekte,

72 Temyiz kararı (n 30) para 54.

73 Temyiz kararı (n 30) para 55.

74 Temyiz kararı (n 30) para 56.

75 Şakir Ansay, Hukuk Tarihinde İslam Hukuku (3. Bası, AÜİF 1958) 7; Hamdi Döndüren, İslam Hukukuna Giriş (Karatay Üniversitesi 2017) 36; Kemal Gözler, 'İslâm Hukukunun Değeri - İslâm Hukuku, Batı Hukukuna Alternatif Olabilir mi?' (2019) <www.anayasa.gen.tr/islam-hukuku.htm> Erişim tarihi 19 Nisan 2021; Vahap Ovac1, 'İslam Hukukunun Karakteristik Özellikleri' (2015) 7(7), Bozok Üniversitesi İlahiyat Fakültesi Dergisi 70.

76 Ovac1 (n 75) 70; Murteza Bedir, 'Fikih to Law: Secularization Through Curriculum' (2004) 11(3) Islamic Law and Society 381.

77 Ansay (n 75) 8; Sayed Hassan Amin, Islamic Law and Its Implications for the Modern World (Londra 1989) 10.

78 Ovac1 (n 75) 71.

79 Taha Jabir Al-Alwani, Source Methodology in Islamic Jurisprudence - Usul al-Fiqh al-Islami (3rd Ed, Londra 2003) 1; Mohammad Hashim Kamali, An Introduction to Shariah (Ilmiah 2006) 12; Wael B. Hallaq, An Introduction to Islamic Law (CambridgeUP 2009) 19; Ahmet Akgündüz, Introduction to Islamic Law (OSAV 2010) 19. 
insanların birbirleriyle ve devletle olan ilişkileri bağlamında var olan ilke ve kurallarını esas almaktadir.

İslam hukuku anlayışında hukukun kaynağı her şeyin yaratıcısı olan Allah’tır. Fıkıh kuralları da Allah’’n peygamberi vasıtasıyla bildirdiği emir ve yasaklardan oluşmaktadır. Buna bağlı olarak İslam hukukunun asıl ve ilk kaynağı Kur’an, ikinci kaynağı da peygamber Hz. Muhammed'in söz ve davranışlarından oluşan sünnettir. ${ }^{80}$ Bununla birlikte İslam hukuku içerisinde icma ${ }^{81}$ ve kıyas $^{82}$, diğer iki önemli kaynak olarak görülmüştür. ${ }^{83}$ Hatta icma ve kıyasa verilen değer göz önünde bulundurularak İslam hukukunun bir içtihat hukuku olduğu benzetmesi yapılmıştır. ${ }^{84}$

Modern hukuk sistemlerinde, bir hukuk kuralı meşruiyetini genel olarak ulusal kanunlardan ve uluslararası sözleşmelerden almaktadır. İslam hukuku ise ulusal kanunların ötesinde bir niteliğe sahiptir. "İslam hukuku" modern hukuk sistemlerinden farklı olarak kaynağı İlahi bir varlığa dayanan, dini temeller üzerine oturtulmuş, bu yönüyle kısmen değişmez bir kaynağa sahip olan bir hukuk sistemidir. ${ }^{85}$ Dini temele dayanması itibariyle sadece dünyevi meseleler ile değil, dünya sonrası yaşama ve ibadetlere dair kurallar da içermekte ve hukuk kuralları ile bir arada bulunmaktadır. Buna bağlı olarak İslam hukukuna aykırı olarak yapılan işlem ve fiillerin dünya hayatında olduğu gibi ahiret hayatında da bir sonucu olacaktır. ${ }^{86}$

İslam hukukunun evrimi, modern hukuk sistemlerinin ortaya çıkmasına kadar olan dönemde içtihatlar üzerinden ilerlemesine karşın modern dönemde kanunlaştırma çalışmaları başlamıştır. $\mathrm{Bu}$ konuda Osmanlı Devleti öncü olmuş ve İslam hukukuna ilişkin belirli ilke ve kuralların kodifikasyonunu gerçekleştirmiştir. 1869-1876 yılları arasında hazırlanan Mecelle’nin özel hukuk alanında yapılan ilk derleme olduğu kabul edilmektedir. ${ }^{87}$ Mecelle'nin etkisi Osmanlı Devleti ile sınırlı kalmamış, Osmanlı Devleti dışında da kullanıldığı ifade edilmiştir. ${ }^{88}$ Ancak Mecelle sonrası dönemde de özellikle kamu hukuku alanında Osmanlı Devleti, başta Fransa olmak üzere Batı yasalarını iktibas etmiştir. ${ }^{89}$ Bu çerçevede zaman içerisinde İslam hukuku kısmen modern hukuk

80 Kamali (n 79) 16; Ansay (n 75) 13-14; Servet Armağan, Anahatlarıyla İslam Hukuku (Işık 2009 ) 42.

81 İcma, İslam bilgini ve müçtehitlerin Kur’an, Sünnet ve bazı mezheplere göre kıyasa başvurarak bir konuda aynı yönde hüküm vermeleri veya verilmiş bir hükümde ittifak etmeleridir. TDV İslam Ansiklopedisi, İbrahim Kafi Dönmez <https://islamansiklopedisi.org.tr/icma> Erişim tarihi 23 Mart 2021; Ansay (n 75) 17-18.

82 Kıyas, hakkında açık hüküm bulunmayan bir meselenin hükmünü, aralarındaki ortak özelliğe veya benzerliğe dayanarak hükmü açıç̧a belirtilen meseleye göre belirlemek anlamına gelmektedir. Bkz. TDV İslam Ansiklopedisi, Yunus Apaydın <https://islamansiklopedisi.org.tr/kiyas\#2-fikih> Erişim tarihi 23 Mart 2021.

83 Kamali (n 79) 17; Ansay (n 75) 17; Armağan, İslam hukukunun kaynakları bakımından sabit kaynaklar - değişken (içtihadi) kaynaklar ayrımını yapmıştır. Yazara göre, sabit kaynaklar Kur’an ve sünnet iken içtihadi kaynaklar icma, kıyas, istihsan, istislah (kamu yararı), örf, Seddi zerayi, istishab, önceki şeraitler ve sahabenin tatbikatıdır. Bkz. Armağan (n 80) 63-86.

84 Ovacı (n 75) 75; Kamali (n 79) 22.

85 Akgündüz (n 79) 25; Armağan (n 80) 29.

86 Akgündüz, (n 79) 25-26.

87 Döndüren (n 75) 134.

88 Döndüren, Mecelle’nin bazı bölümlerinin Lübnan'da 1934, Suriye’de 1949, Irak’ta 1951, Ürdün’de 1977 yılına kadar uygulandığını ifade etmektedir. Bkz. Döndüren (n 75) 135.

89 Fransız kanunlarının iktibası suretiyle yasalaşan bazı Osmanlı kanunları şunlardır: 1850 tarihli Kanunname-i Ticaret ve 
sistemlerine entegre olmaya başlamıștır. Yine de İslam hukuku ile modern hukuk sistemleri arasında tam bir entegrasyonun olduğu söylenemez. Kanunlaştırma çalışmaları yapılsa da kodifiye edilen kurallar arasında farklılıkların olması muhtemeldir, zira devletlerin, İslam hukuku içerisinde yer alan aynı mezhep ve okulların ortaya koydukları ilke ve içtihatları kodifiye etmesi söz konusu değildir.

İslam hukukunun hukuk sistemine doğrudan kaynaklık ettiği devletler bakımından ortaya çıkan uyuşmazlıklarda alternatif uyuşmazlık çözüm yöntemleri bağdaştırıcı bir role sahip olmuştur. Yine de modern hukuk sistemleri içerisinde İslam hukukunun dışlandığı bazı davalar ile karşılaşılmaktadır. Uluslararası kaynaklarda, İslam dünyasının tahkime bakış açısını olumsuz olarak etkilediği ifade edilen davalardan ${ }^{90}$ birisi olan Petroleum Development (Trucial Coasts) Ltd. v. Sheikh of Abu Dhabi davasında hakem Lord Asquith, İslam hukukuna dayanan Abu Dabi hukukunun uygulanacağını tespit etmesine rağmen "Kura’an'dan biraz yardım alarak Abu Dabi monarkının geniş takdir yetkisine bağh adalet sisteminin” kabul edilemeyeceğini öne sürerek uyuşmazlığı İngiliz hukukuna göre çözümlemiştir. ${ }^{91}$ Ruler of Qatar v. International Marine OilCo. Ltd davasında da hakem, uygulanacak hukuk olarak İslam hukukunun ilgili sözleşmenin yorumlanmasında yetersizliğini ifade ettikten sonra ilgili sözleşmeye Katar hukukunu uygulamayı reddetmiştir. ${ }^{92}$ Fakat bu kararlar devam eden yıllarda yoğun eleştiri almıştır. ${ }^{93}$

\section{B. ISLAM HUKUKUNUN SEÇILMESINE ILIŞKIN OLASILIKLAR}

Taraflar arasında uygulanacak hukuk olarak İslam hukukunun seçimi genel olarak dört farklı şekilde yapılabilmektedir: İlk olarak İslam hukuku kurallarının uygulandığı ya da esas alındığı devletler bakımından ilgili devletin hukuku seçilebilir. Bu durumda belirli bir ülke hukuku seçildiği için geçerli bir hukuk seçiminin kabulü muhtemeldir. İslam hukukunu - bir başka deyişle Şeriatı devletin hukuki ve siyasi yapısının temeline koyan ülkeler Arap yarımadasında, Kuzey Afrika'da ve Güneydoğu Asya’da bulunmaktadır. Bu durumda örneğin Suudi Arabistan hukukunun taraflarca uygulanacak hukuk olarak seçilmesi mümkündür ve bir devletin hukuku seçildiği için dolaylı olarak İslam hukukunun da uyuşmazlığın çözümünde kullanılabileceği söylenebilir. Ancak İslam hukuku daha geniş bir kapsama sahiptir ${ }^{94}$ ve İslam hukukunu benimseyen ülkeler (örneğin İran ve Suudi

1863 tarihli Ticareti Bahriye Kanunnamesi, 1861 tarihli Usul-i Muhakeme-i Ticaret Nizamnamesi, 1879 tarihli Usul-i Muhakemat-1 Cezaiye Kanunu. Osmanlı dönemindeki kanunlaştırma hareketleri için bkz. Mustafa Şentop, 'Tanzimat Dönemi Kanunlaştırma Faaliyetleri Literatürü’ (2005) 3(5) Türkiye Araştırmaları Literatür Dergisi 652-659; Musa Gümüş, ‘Osmanlı Devleti’nde Kanunlaştırma Hareketleri - İdeolojisi ve Kurumları' (2013) Tarih Okulu (Sayı XIV) 166 vd.

90 Ibrahim Fadlallah, 'Arbitration Facing Conflicts of Culture: The 2008 Annual School of International Arbitration Lecture' sponsored by Freshfields Bruckhaus Deringer LLP (2009) 25(3) Arbitration International, 307-308; Blackaby/Partasides/ Redfern/Hunter (n 29) 226.

91 Petroleum Development (Trucial Coast) Ltd. v. Sheikh of Abu Dhabi (1951) 18 I.L.R. 144. Abdullah Mohammed Alsaidi, Petroleum Arbitration: Applicable Law and Appropriate Arbitral Forum (A Study of Petroleum Disputes in Arab Countries) (University of London 2004) 75.

92 Ruler of Qatar v. International Marine Oil Co. (1953) 20 ILR 534. Erişim: Alsaidi (n 91) 82.

93 Fadlallah (n 90) 313; Blackaby/Partasides/Redfern/Hunter (n 29) 226; Julio Colon, 'Choice of Law and Islamic Finance' (2011) 46(2) Texas International Law Journal 414.

94 Doktrinde İslam hukukunun bu yönüyle ulusal-üstü (trans-national) olduğu ifade edilmiştir. Bkz. Anowar Zahid and 
Arabistan) yan yana koyulduğu zaman aynı konuda farklı kurallar ile karşılaşmak mümkündür. Nitekim bu durum İslam hukukunun kapsamının belirlenmesinde zorluk çıkarmaktadır.

İkinci olarak İslam hukukuna ilişkin sektörel veya ticari kuralları yansıtan AAOIFI Kuralları gibi İslam dini referanslı bazı metinlere yapılan atıflardır. Bu durumda da uygulanacak hukuk konusu tartışmaya pek açık değildir. Zira taraflarca atıf yapılan kuralların bir devlet hukuku olmadı̆̆ı açık olmakla birlikte 'uygulanacak hukuk kuralları' kapsamına dâhil edilecektir. Bu yönüyle taraflarca seçilen hukuk kuralları, devlet mahkemeleri açısından uygulanacak hukuk olarak değil ancak sözleşme hükmü olarak işlev görecek iken tahkim ve diğer alternatif uyuşmazlık çözüm yöntemleri için uyuşmazlığın esasına uygulanacak hukuk kuralları rolüne sahip olabilirler.

Bunun dışında, başka herhangi bir hukuk ya da kurallar bütünü zikredilmeksizin taraflar arasındaki belirli bir uyuşmazlığın İslam hukukuna göre çözümleneceği ifade edilebilir. Uyuşmazlık çözümüne ilişkin bu klozun ne şekilde nitelendirileceği ve doğuracağı hukuki sonuçlar tartışmaya açıtır. Şüphesiz uyuşmazlık çözüm merciinin ulusal mahkemeler ya da hakem heyeti (veya alternatif uyuşmazlık çözüm merciindeki ilgili merci) olmasına göre sonuç farklılık arz edecektir. Bu ihtimalde asıl tartışma konusu, uyuşmazlığın esasına uygulanmak üzere seçilen İslam hukukunun bir anasyonel hukuk kuralı olarak değerlendirilip değerlendirilemeyeceği hususunda toplanmaktadır. Zira İslam hukukunun kavramsal olarak bir devlet hukuku olmadığı açıktır. Eğer taraflar arasındaki seçim anasyonel hukuk kuralı olarak değerlendirilirse İslam hukuku kurallarının sözleşmeye dâhil edilmesi ve - uygulanacak devlet hukukunun emredici hükümlerine aykırı olmaması şartıyla - sözleşme hükmüymüş gibi kabul edilmesi mümkündür.

Son olarak belirli bir devlet hukuku seçilmekle birlikte İslam hukukunun temel veya belirli ilkelerinin uygulanacağ ${ }_{1}$ ifade edilmektedir. Bu yöntem karma yöntem olarak ele alınmaktadır. ${ }^{95}$ $\mathrm{Bu}$ çalışmada incelenen Beximco kararındaki hukuk seçimi bu türden bir seçimdir. Bu durumda salt İslam hukukunun uygulanacak hukuk olarak seçilebilmesine ilişkin tartışmaların yanı sıra İslam hukukunun bir devlet hukuku ile birlikte seçilip seçilemeyeceği sorusu gündeme gelmektedir. Bilindiği üzere birden fazla hukukun seçimi geçerli bir hukuk seçimi değildir, çünkü bu hukuklardan hangisinin uygulanacağı belirsiz olup böyle bir hukuk seçiminin 'patolojik' bir yapısının olduğu söylenebilir. ${ }^{96}$ Ancak uygulanacak hukuk olarak bir devlet hukukunun yanı sıra sözleşme hükümleri haline gelecek olan bir anasyonel kurallar serisinin seçilmesi mümkün olabilir. Zira bu ihtimalde taraflarca seçilen anasyonel hukuk kuralları sözleşme hükmü haline gelir ve geçerliliği seçilen devlet hukukunun emredici hükümleri ile sinırlandırılır. Ancak tahkim bakımından anasyonel hukuk kuralları da uygulanacak hukuk olarak seçilebileceği için bir yandan anasyonel hukuk kurallarının bir yandan da bir devlet hukukunun seçimi geçersizlik yaptırımı ile karşılaşacak niteliktedir.

Hasani Mohd Ali, 'Shariah As A Choice Of Law In International Islamic Financial Contracts: Shamil Bank Of Bahrain Case Revisited' (2013) 10(1) US-China Law Review 31.

95 Zahid / Mohd Ali (n 94) 33; Colon (93) 21; Junius (n 9) 543.

96 Patolojik kavramı daha çok tahkim anlaşmaları için kullanılsa da kanımızca hukuk seçimi anlaşmaları için kullanılması da mümkündür. Patolojik tahkim anlaşmaları hakkında bkz. Ozan Tok ve Sumru Akter, 'Patolojik ve Asimetrik Tahkim Anlaşmalarının Değerlendirilmesi’ iç Mustafa Erkan ve Candan Yasan (edr), Tahkim Okulu Paneller Serisi Cilt I (Oniki Levha 2020) 57-101. 


\section{LEX MERCATORIA ILE KARŞILAŞTIRMALI OLARAK ISLAM HUKUKUNUN UYGULANACAK HUKUK OLARAK SEÇILEBILMESI}

İslam hukukunun, anasyonel hukuk kuralları içerisinde yer almasındaki en büyük engelin, İslam hukukuna ilişkin prensip ve kuralların tespit edilmesinde yer alan zorluk olduğu anlaşılmaktadır. Nitekim hem doktrinsel görüşlerde ${ }^{97}$ hem de yukarıda belirtilen İngiliz mahkemesi kararında, İslam hukukunun temel prensipleri arasında dahi mezhep ve döneme göre görüş farklılıklarının olduğu, taraflar arasında kastedilen hukukun hangi okul/görüş/mezhep yorumunun esas alınacağının belirlenemeyeceği; bu sebeple sadece İslam hukukuna yapılan atfın yeterli olmayacağı ifade edilmektedir.

\section{GENEL OLARAK LEX MERCATORIA}

Lex mercatoria, sınırları yazılı kaynaklar ile belirlenmemiş bir hukuk kaynağı olsa da uluslararası tahkim hukukunda, uygulanacak hukuk olarak seçilebilmektedir. ${ }^{98}$ Gerçekten de pek ulusal ve uluslararası tahkim mevzuatlarında kabul edildiği üzere, lex mercatoria, herhangi bir milli hukuk denetimi olmaksızın doğrudan esasa uygulanmak üzere seçilebilmekte ${ }^{99}$ ya da tahkim düzenlemelerinin izin vermesi halinde doğrudan hakemler tarafından uygulanabilmektedir. ${ }^{100}$ Hatta lex mercatoria yerine hukukun genel ilkeleri (general principles of law), uluslararası ticarette geçerli adet ve teamüller (trade usages and practices in international law), uluslararası ticaret hukukunda kabul edilen genel prensiplerin (general principles of transnational commercial law) seçilebileceği ve bunların da lex mercatoria’nın seçimi ile aynı anlama geldiği ifade edilmektedir. ${ }^{101}$

Lex mercatoria, uluslararası ticari işlemlerin esasına, hukuk sistemlerinden bağımsız olarak, ticari adet ve teamüller vasıtasıyla uygulanan kurallar bütünüdür. ${ }^{102}$ Lex mercatoria’nın hukuki niteliği konusunda üç temel yaklaşım bulunmaktadır. Bunlardan birincisi, lex mercatoria'nın milli hukuk sistemlerinin dışında ve onlardan bağımsız ayrı bir hukuk sistemi olarak gören görüştür. ${ }^{103}$ İkinci

97 Junius (n 9) 542; Colon (93) 424; Killian Balz, 'Shamil Bank of Bahrain v. Beximco Pharmaceuticals and Others' (2004) 9(1) Yearbook of Islamic and Middle Eastern Law Online 510; Jonathan Ercanbrack, The Transformation of Islamic Law in Global Financial Markets (CambridgeUP 2015) 315; Faisal Kutty, 'The Sharia Factor in International Commercial Arbitration' (2006) 28(3-4) Loyola of Los Angeles International and Comparative Law Review 565, 596.

98 Tolga Ayoğlu, Uluslararası Ticari Sözleşmelere Uygulanan Genel Prensipler, Maddi Hükümler ve Ticari Adet-Teamüller Olarak Lex mercatoria (Vedat 2011) 86; Harold J Berman and Colin Kaufman, 'The Law of International Commercial Transactions (Lex Mercatoria)' (1978) 19(1) Harvard Law Journal 221; Filip De Ly, International Business Law and Lex Mercatoria (Emerald 1992) 7; Arzu Oğuz, Lex Mercatoria (Yetkin 2004) 187; Güven (n 29) 27; Clive Schmitthoff, 'International Trade Usages'(ICC 1987) ICC Yayın no. 440/4, Institute of International Business Law and Practice Newsletter 48-49.

99 Bkz. yukarıda Bölüm I.B.

100 Özel, Tahkim (n 29) 142; Güven (n 29) 29-32; Ayoğlu (n 98) 88-89.

101 Ayoğlu (n 98) 87.

102 Ayoğlu (n 98) 2; Berman/Kaufman (n 98) 222; De Ly (n 98) 5; Güven (n 29) 29.

$103 \mathrm{Bu}$ görüş öncelikle Berthold Goldman tarafından ortaya atılmıştır. Berthold Goldman, The Suez Company - an International Company (Le Monde 1956); Aleksandar Goldstajn, 'Usages of Trade and Other Autonomous Rules of International Trade According to the UN (1980) Sales Convention' iç Petar Sarcevic and Paul Volken (edr), International Sale of Goods (Oceana 1986) 70. Bu görüșü savunan yazarlar hakkında bkz. Ayoğlu (n 98) 33-39. 
görüş ise lex mercatoria’yı milli hukuk sistemlerinin desteğiyle ve bu sistemlerin bir parçası olarak uygulanan uluslararası ticarete özgü maddi hukuk kuralları olarak kabul etmektedir. ${ }^{104}$ Son olarak bir anlamda ilk iki görüşü birleştiren üçüncü bir görüş, lex mercatoria’nın bağımsız bir hukuk düzeni oluşturmayan ancak bağımsız bir hukuk düzeni gibi uyuşmazlığın esasına uygulanan, bağlayıcılığını uluslararası planda gördükleri genel kabulden alan milletlerarası ticarete özgü maddi norm ve kurallardan oluştuğunu ifade etmektedir. ${ }^{105}$

Bununla birlikte lex mercatoria'nın bulunduğu çerçevenin daha iyi anlaşılabilmesi için lex mercatoria'nın kaynaklarını göz önünde bulundurmak gerekmektedir. Bir yaklaşıma göre lex mercatoria'nın kaynaklarını uluslararası konvansiyonlar, model kanunlar ve ticari örf-adet'in oluşturduğu kabul edilmişken (sınırlayıcı yaklaşım), diğer bir yaklaşım yukarıda belirtilenlerin dışında sözleşmeler hukukunun genel prensipleri, standart sözleşmeler, genel işlem şartları, davranış kuralları ve hakem kararlarını da lex mercatoria’nın kaynağı olarak ele almaktadır (geniş yaklaşım). ${ }^{106}$ Buradan da bakıldığı zaman lex mercatoria’nın uluslararası ticarete ilişkin karşılaştırmalı hukuk birikimi ve yerleşik kural ve uygulamaları yansıttığı anlaşılmaktadır.

\section{ISLAM HUKUKUNUN SEÇILMESINDE TARAF IRADESININ GEÇERLILIĞi}

Bilindiği üzere hukuk seçimi, geçerliliğini hukuk sisteminin izin verdiği ölçüde tarafların iradesinden almaktadır. Gerçekten de sözleşmeler alanında irade serbestisi prensibi en geniş anlamda geçerli olmakta ve yabancılık unsuru içeren sözleşmesel ilişkiler bakımından sözleşmeyi yönetecek olan veya uyuşmazlığın çözümünde kullanılacak olan hukuk sistemi taraflarca belirlenebilmektedir. Alternatif uyuşmazlık çözüm yöntemleri bakımından irade serbestisi biraz daha geniş tutulmakta ve belirli hukuk kuralları seçilerek uygulanacak hukuk belirlenebilmektedir. Yine irade serbestisi prensibinin bir parçası olarak belirli kurallara atıfta bulunarak ilgili kuralların sözleşmeye dâhil edilmesine olanak tanınmaktadır.

Lex mercatoria, yukarıda üzerinde durulduğu üzere, ticari adet ve teamüller vasitasıly uluslararası ticari işlemlerin esasına, hukuk sistemlerinden bağımsız olarak uygulanabilmektedir. Oysa lex mercatoria, yazılı kurallar olmayıp uluslararası ticarete ilişkin karşılaştırmalı hukuk birikimi ve yerleşik kural ve uygulamaları yansıtmaktadır. Bu durumda lex mercatoria ile İslam hukuku hakkında hukuk seçimi bakımından nasıl bir fark olabileceğinin değerlendirilmesi gerekmektedir. Zira İslam hukuku ya da Şeriat kavramları bakımından lex mercatoria ile benzer değerlendirmelerin yapılması mümkündür. İslam hukukunun milli hukuk sistemlerinden bağımsız ya da bazı milli hukuk sistemlerinin desteğiyle ve bu sistemlerin bir parçası olarak geliştiği ifade edilebilir. Bununla birlikte bazı devletlerde Müslümanların taraf olduğu uyuşmazlıklar bakımından uyuşmazlığın İslam hukukuna göre ya da İslam hukukunun genel prensiplerine göre çözülmesi asıldır. Nitekim karşılaştırmalı hukukta bazı kaynaklarda İslam hukukunun lex mercatoria içerisinde değerlendirildiği

104 Bu görüşü savunan yazarlar hakkında bkz. Ayoğlu (n 98) 45-51.

105 Bu görüşü savunan yazarlar hakkında bkz. Ayoğlu, (n 98) 51-56.

106 Ayoğlu (n 98) 2. 
görülmektedir. ${ }^{107}$ Buna karşın İngiliz yargısının lex mercatoria’yı uygulanacak hukuk olarak kabul ederken Şeriat prensiplerinin uygulanmasını reddetmesi, bazı yazarlarca eleştirilmiştir. ${ }^{108}$ Söz konusu kararı eleştiren Zahid/Ali'ye göre, taraflı bir yaklaşım sergilenmiş, irade serbestisi prensibine ve İslam hukukuna bir saygısızlık yapılmıştır. ${ }^{109}$

İslam hukuku ya da Şeriat kavramlarının ulusal-üstü (transnational) olduğu, yani bir devlet hukukunun dışında fakat pek çok devleti ilgilendiren bir kurallar bütünü olduğu açıktır. ${ }^{110}$ Bununla birlikte Beximco kararında öne sürüldügüü üzere çok sayıda farklı yorum ve görüş ile karşılaşılmaktadır. İslam dini ve buna bağlı olarak kuralları, mezhepler özelinde bir gelişim göstermiştir. Lex mercatoria ile İslam hukuku arasındaki temel fark buradan kaynaklanmaktadır. İslam hukuku kuralları, lex mercatoria'ya nazaran daha az kurumsallaşmış ve yeknesaklaştırılmıştır. Lex mercatoria içerisinde var olduğu kabul edilen Viyana Sayım Sözleşmesi, Avrupa Sözleşme Hukuku İlkeleri, UNIDROIT ilkeleri ve uluslararası ticaret hukukunun temel prensipleri bakımından büyük benzerliklerin olduğu söylenebilir. Buna karşın İslam hukukunda bir konuda farklı görüşlerle karşılaşmak daha olasıdır. Yine de İslam hukuku içerisinde bazı temel prensiplerin ortak olduğu ya da genel kabul gördüğü ifade edilebilir. Bazı eserlerde ticari ve ekonomik alanda genel kabul gören kurallar bütününü ifade etmek üzere lex mercatoria Islamica kavramı kullanılmıştır. ${ }^{111}$

Doktrinde; İslam ülkelerinde dahi faiz, garar ve murahaba gibi İslami finansa ilişkin kavramların çerçevesinin yasal olarak belirlenmediği, bu sebeple Batı dünyasında İslam hukukunun uygulanmasının 'belirsizlik' gerekçesiyle reddedildiği tespiti yapılmıştır. ${ }^{112}$ Bununla birlikte İslam ülkeleri arasında aynı konuda farklı kural ve uygulamaların bulunması sözleşmeye ve/veya uyuşmazlığı taraflarca seçilen İslam hukukunun uygulanmasına engel görülmüştür. Buradan hareketle uygulanacak hukuk kurallarının seçiminde belirlilik unsurunun büyük önem arz ettiği görülmektedir. Bir kurumun çıkardığg yazılı kurallar bütününe, bir uluslararası sözleşmeye, belirli bir sektörde mutad hale gelen prensiplere yapılan atıflar ile belirli bir ülkenin hukukunun seçimi bu belirliliği sağlamaktadır. Belirlilik unsuru sadece seçilen hukuk kurallarının içeriği bakımından değil, ayrıca hukuk seçimi klozunun lafzı bakımından önem arz etmektedir. ${ }^{113}$ Bu hususta Türk mahkemelerinin de katı bir yaklaşımı bulunmaktadır. ${ }^{114}$

107 Blackaby/Partasides/Redfern/Hunter (n 29) 225.

108 Zahid / Mohd Ali (n 94) 31-34; Kareem Adebayo Olatoye and Abubakri Yekini, 'Choice of Law As the Governing Law in Islamic Finance Contracts: The United Kingdom and Nigerian Perspectives’ (2017) 25(1) IIUM Law Journal 158-159; Ahmad Q. Farah and Rasha M. Hattab, 'The Application of Sharī'Ah Finance Rules in International Commercial Arbitration' (2020) 16(1) Utrecht Law Review 130.

109 Zahid / Mohd Ali (n 94) 34.

110 Zahid / Mohd Ali (n 94) 31.

111 Bruno Martin Baumeister, 'Lex Mercatoria Islamica: Sharia as Choice of Law under Rome I Regulation' Repositorio Universidad Pontificia Comillas <https://repositorio.comillas.edu/xmlui/handle/11531/27196> Erişim tarihi 21 Mart 2021; Zahid / Mohd Ali (n 94) 31; Michelle Sanson, Essential International Trade Law (2nd Ed, Australia 2005) 6; Colon (93) 416.

112 Colon (93) 426.

113 Chuah (n 9) 144.

114 “.. 02.04.2011 tarihli sözleşmenin 4. maddesi, “Taraflardan her biri, iş bu akdin süresinden önce feshini ancak M.K.nun 672. maddesinde yer alan önemli hususların vukuunda isteyebilirler ve ancak bu durumda akit süresinden önce feshedilir" 
Ancak kanımızca bu hususta tarafların gerçek iradesinin ortaya çıkarılması konusunda, yargılamayı yapan merciin gayret göstermesi ve gerekli durumlarda taraflara başvurulması gerekmektedir. Bu durumda yargılama merciinde, gerekli inceleme yapıldıktan sonra, tarafların iradesi konusunda bir kanaat oluşmamışsa, uygulanacak hukuka dair seçimin geçersiz kılınması mümkün olmalıdır. Bir başka deyişle, somut olayın şartlarına göre tarafların iradesine geçerlilik tanımak mümkün ise İslam hukukunun ilgili prensiplerine etki tanınmalıdır, fakat uygulanacak kurallara dair belirsizlik bulunmakta ise geçersizlik yaptırımının üzerinde durulması beklenmektedir.

Son olarak İngiltere dâhil bazı ülkelerde yabancı hukukun hukuk olarak değil de vakıa olarak uygulandığını vurgulamak gerekir. Bu durumda eğer İslam hukuku seçilmesine rağmen taraflarca talep edilmemiş veya İslam hukukunun içeriğine dair bilgi getirilmemiş ya da uzman mütalaasına başvurulmamış ise İngiliz hukuku uygulanmaya devam edecektir. ${ }^{115}$ Kıta Avrupası hukukunun bir parçası olarak Türk hukukunda ise yabancı hukuk bir hukuk olarak uygulanmaktadır. Bir başka deyişle taraflarca seçilen hukuk, re’sen ve yabancı hâkim nasıl uyguluyorsa o şekilde uygulanmalıdır. ${ }^{116}$

\section{SONUÇ}

İrade serbestisi prensibi gereğince yabancılık unsuru içeren sözleşmesel ilişkilerde tarafların uygulanacak hukuku seçebilecekleri uzun zamandır kabul görmektedir. İrade serbestisinin sınırları tahkim ve diğer alternatif uyuşmazlık çözüm yöntemleri bakımından daha da geniş olup uygulanacak hukuk olarak bir devlet hukuku yerine anasyonel hukuk kuralları seçilebilmektedir. Nitekim uluslararası ticari uyuşmazlıklarda lex mercatoria kavramı, bağımsız bir maddi hukuk kuralları bütünü olarak gelişmiş ve uygulama tarafından genel kabul görmüştür.

İslam ülkelerinin uluslararası ticarette rollerinin artmasıyla birlikte uyuşmazlıkların çözümünde İslam hukukunun kullanılması daha fazla gündeme gelmektedir. Özellikle Batı kökenli laik hukuk düzenleri içerisinde İslam hukukunun ne suretle uygulanacağı konusu bazı belirsizlikler ve tartışmalar barındırmaktadır. Bu hususta hâkim veya hakemleri en çok zorlayan hususların, hâkim ya da hakemlerin İslam hukukuna yabancı olması, İslam hukukunun kapsamının ve

hükümünü haizdir. Bu maddeye göre, taraflar akdin feshinde Medenî Kanunun 672. maddesine yollama yapmışlardır. Yollama yapılan kanun, Yunan Medenî Kanunudur. Çünkü Türk Medenî Kanunun 672. Maddesi Miras Hukukuna ilişsin iken, Yunan Medenî Kanunun 672. maddesi iş akdinin feshini düzenlemektedir1 ve "Taraflardan her birisi haklı sebepler ile önceden herhangi bir önel vermeksizin sözleșmeyi her zaman feshetme hakkını haizdir. İşbu hak sözleșme ile de bertaraf edilemez." hükmüne yer vermektedir. Bu durumda taraflar, sözleșmenin feshinde Yunan Medenî Kanununa göndermede bulunmuşlardır. Öncelikli mesele tarafların bu şekilde göndermede bulunmasının taraflar arasında bir hukuk seçimi anlamina gelip gelmediğini değerlendirmektir... Taraflar arasındaki iş sözleşmesinin bahse konu 4. maddesinin içeriği ve yukarıdaki 24. madde dikkate alındığında, tarafların yalnızca sözleșmenin feshi bakımından Yunan Medeni Kanununun uygulanmasın amaçlamış oldukları, aralarında uygulanacak hukuku tereddüde yer vermeyecek şekilde kararlaştırmış olduklarından söz edilemeyeceği; nitekim daval vekilinin temyiz itirazlarında da iş sözleşmesinde uygulanacak hukuk seçimi yapılmadığının ifade edildiği gözetildiğinde taraflar arasındaki iş sözleşmesine, 5718 sayıl Kanunun 27/2. maddesine göre iş̧̧inin işini mutad olarak yaptı̆̆ı işyeri hukukunun uygulanacağını kabul etmek gerekir.” Y. 22. HD. E. 2016/9339 K. 2019/16564 T. 18.09.2019 Legalbank Elektronik Hukuk Bankası, Erişim tarihi 17 Kasım 2020.

115 Kanunlar ihtilafı kurallarının ve uygulanacak hukukun vakıa olarak değerlendirilmesi hakkında bkz. Can Yöney, Yabancı Hukukun Uygulanması (Oniki Levha 2018) 55-61.

116 Yöney (n 115) 51-55. 
kurallarının belirlenmesinde yaşanan zorluklar, bir devlet hukuku olmaması sebebiyle bazı ülkelerde uygulanmasının kabul edilmemesi olduğu anlaşılmaktadır. Öte yandan İslam hukukuna ilişkin olarak ortaya konan bazı kararlar - Arap yarımadası gibi - ekonomik etkinliğin olduğu bazı bölgelerde, uluslararası hak arama çalışmalarına ve özellikle tahkime karşı olan bakış açısını olumsuz etkilemektedir.

Uluslararası uyuşmazlıklarda İslam hukukunun uygulanmasına ilişskin bu çalışmada Shamil Bank of Bahrain v. Beximco kararı inceleme konusu yapılmıştır. İngiliz devlet mahkemeleri önünde görülen davada faize dayalı olarak yapılan sözleşmelerin geçerliliği, buna bağlı olarak uygulanacak hukuk olarak İslam hukukunun seçilip seçilemeyeceği tartışılmıştır. Taraflarca yapılan sözleşmede uygulanacak hukuk klozu olarak şu ifadeye yer verilmiştir: "Yüce Şeriat prensiplerine bağh olarak bu sözleşme İngiliz hukukuna tabi olacak ve İngiliz hukukuna uygun olarak yorumlanacaktır." İlk derece mahkemesinde; Roma Konvansiyonu'na göre uygulanacak hukuk olarak ancak bir devlet hukukunun seçilebileceği, İslam hukukunun bir devlet hukuku olmadığı, aynı anda iki devletin birden seçilemeyeceği, ayrıca 'Yüce Şeriat prensipleri' ile taraflarca ortaya konulan seçimde İslam dininin çok sayıda yorumundan hangisinin ya da hangilerinin uygulanmasını gerektiğinin belirlenemediği, çok fazla belirsizlik barındırdığı gerekçeleriyle, İslam hukukunun uygulanması reddedilmiştir. Bu suretle davacı lehine hüküm kurulmuş, bu karar İngiliz Yüksek Mahkemesi tarafından onaylanmıştır. 2004 tarihli bu karardan sonra lehe ve aleyhe doktrinsel değerlendirmeler yapılmıştır. İslam hukukunun uygulanacak hukuk olarak seçilip seçilememesine ilişkin bu tartışma hâlâ önemini korumaktadır.

Konu hakkındaki esas tartışma İslam hukukunun anasyonel hukuk kuralları olarak tanımlanabilmesi üzerinde toplanmaktadır. Zira İslam hukukunun bir devlet hukuku olmadığı açıktır ve seküler devlet mahkemeleri nezdinde salt İslam hukukunun uygulanacak hukuk olarak seçilmesi mümkün görünmemektedir. Bundan ziyade İslam hukukunun esas alındığı bir ülke hukukunun seçilmiş olması sonuç doğuracaktır. Ancak eğer İslam hukuku (ya da Şeriat) anasyonel hukuk kuralları olarak değerlendirilecek olursa, ilgili ilke ve kurallar, sözleşme hükmü olarak kabul edilebilecek ve alternatif uyuşmazlık çözüm yöntemleri açısından uygulanacak hukuk kuralları içerisinde değerlendirilerek uyuşmazlığın esasına uygulanmak üzere taraflarca seçilebilecektir.

İslam ülkeleri ve tacirleri açısından uluslararası alanda İslam hukukunun uygulanması genellikle arzu edilmektedir. Ancak İslam hukukunun -anasyonel hukuk kuralları olarak dahi - uygulanması bakımından en büyük engelin, İslam hukukunun sahip olduğu geniş kapsam ve birbirinden farklı yorum ve uygulamalar olduğu anlaşılmaktadır. Gerçekten de uluslararası ticari örf adet hukuku olarak da bilinen lex mercatoria uygulanacak hukuk olarak seçilebilirken İslam hukukunun seçilebilmesinde genel bir kabulün olmaması, "İslam hukuku”nun lex mercatoria'dan farklı olarak kurumsallaşamamasından ve yeknesak bir bütün oluşturamamasından kaynaklanmaktadır. Farklı mezhep ve ülkelere bağlı olarak bir hukuki işlemin İslam dinine göre caiz (hukuka uygun) olup olmadığ ${ }_{1}$ değişebilmektedir. Nitekim İslami bankacılık adı altında faaliyet gösteren pek çok finansal kuruluşun işlemlerinin İslam’a uygunluğu, kurum bünyesinde oluşturan Kurullar tarafından belirlenmektedir. Bu durumdan sektörel anlamda da olsa İslam hukuku hakkında bağlayıcı bir otorite bulunmadığı anlaşılmaktadır. Bu eksikliği gidermek adına AAOIFI gibi sivil ve bağımsız kurumlar 
vasıtasıyla İslami kurallar somutlaştırılmaktadır. Ancak bu kurumların henüz "İslam hukuku”nu tayin ettiğini ileri sürmek mümkün görünmemektedir. Yine de bu kurumların zaman içerisinde lex mercatoria Islamica'yı inşa etmesi mümkündür.

Hukuk seçimi, irade serbestisi prensibinin bir parçasıdır. İrade serbestisi prensibinin kabul edildiği alanlarda tarafların gerçek iradesinin ortaya çıkarılması gerekmektedir. Nitekim pek çok ulusal kanunda ve tahkim kurumlarının kurallarında açık hukuk seçiminin yanı sıra zımni hukuk seçiminin de geçerli kabul edildiği görülmektedir. Zımni hukuk seçiminde tarafların gerçek iradesi, hükümlerin yorumlanması suretiyle tayin edilmektedir. Bu çerçevede İslam hukuku kuralları bakımından da tarafların açı iradesinin hilafına bir yorum yapmak hukuken doğru olmayacaktır. İslam hukuku içerisinde çeşitli alanlarda farklı görüş ve yorumların bulunduğu, özellikle Sünni-Şii gibi ya da bunlar içerisinde alt ayrımların (Hanefilik, Şafilik, Malikilik, Hanbelilik gibi) bulunduğu açıktır. Buna karşın bazı prensipler açısından belirgin görüş farklılıkları bulunmamaktadır. Faizin yasaklılığı konusu da bilinen ve ihtilaf bulunmayan İslam ticaret hukuku prensiplerinden birisidir. Dolayısıyla taraflar, genel İslami prensiplere atıf yapmışlarsa faiz yasağının da göz önünde bulundurulması gerekmektedir, zira tarafların bu yönde bir iradesinin bulunduğu kabul edilebilir. Bu durumda tarafların iradesi hilafına taraflarca yapılan seçim geçersiz kılınmamalıdır. Ancak faiz yasağının uyuşmazlığın esasına uygulanacak olan hukukun kamu düzenine aykırı olduğu kabul edilebilirse, bu konuda lex arbitri'ye başvurulabilecektir.

Shamil Bank of Bahrain v. Beximco kararını da bu bağlamda değerlendirmekteyiz. İlgili uyuşmazlıkta "Yüce Şeriat prensiplerine bağlı olarak bu sözleşme İngiliz hukukuna tabi olacak ve İngiliz hukukuna uygun olarak yorumlanacaktır " klozu ile karma bir hukuk seçimi yapılmıştır. Kanımızca, tarafların mahkemeler nezdinde esas uygulanacak hukuk olarak İngiliz hukukunu seçtiği, ancak bundan önce şeri hukuk prensiplerinin dikkate alınması gerektiği, şer’i hukuk ile İngiliz hukukunun emredici hükümlerinin çatıştığı alanda İngiliz hukukunun uygulanacağ 1 , İngiliz hukukunun izin verdiği ölçüde temel şeriat prensiplerinin uygulama alanı bulacağı anlaşılmaktadır. Bu perspektiften bakarak denilebilir ki sözleşme serbestisini ön planda tutan İngiliz hukukunda taraflar arasında yapılan anlaşma ile faizin uygulanmayacağının belirlenmesi mümkündür. "Şeriat ilkelerine bağh olarak" ifadesine dayanarak temel İslam hukuku prensiplerinin sözleşmeye dâhil edildiğinin kabulü mümkün ve yerindedir. Ancak faiz konusunda İslami görüş ve disiplinler arasında belirgin bir fark olsaydı bu durumda, belirsizlik sebebiyle İslam hukuku prensipleri gözetilmeden doğrudan İngiliz hukukuna göre çözümlenmesi yerinde olurdu.

Ancak yukarıda belirtildiği üzere İslami bankacılık uygulamasında bağlayıcı Şeriat otoriteleri bulunmamakta, genellikle "Danışma(veya Denetim) Kurulu” ve benzeri kurumsal yapılar vasıtasıyla yapılan işlemlerin İslam hukukuna uygunluğu ya da aykırılı̆̆ı değerlendirilmektedir. Somut uyuşmazlık bakımından 1995 ve 1996 tarihli murabaha anlaşmaları ile 1999 ve 2001 yıllarında yapılan sözleşme değişikliklerinin faiz içerdiği, bu sebeple (Şeriata göre) geçersiz olması gerektiği ifade edilmiştir. Oysa bu sözleşmeler bankanın Dini Denetleme Kurulu tarafından Şeriata uygun bulunmuştur. İslam hukuku uzmanları tarafından dolaylı olarak söz konusu işlemlerin faiz içerdiği ve İslam hukukuna aykırı olduğu sonucuna ulaşılsa dahi ilgili sözleşmelerin taraflar arasında 
karşılıklı müzakere yoluyla yapıldığı ve taraflarca Şeriata uygunluğunun kabul edildiği göz önünde bulundurularak sözleşmenin geçersizliğini ileri sürmenin dürüstlüğe aykırı olduğu kabul edilebilir.

Yukarıda yapılan değerlendirmeler Türk hukuku açısından da geçerlidir. Yani taraflar arasındaki hukuk seçimi klozunda "Yüce Şeriat prensiplerine bağlı olarak bu sözleşme Türk hukukuna tabi olacak ve Türk hukukuna uygun olarak yorumlanacaktır“ ifadesi kullanılmışsa belirliliği sağladığı ölçüde Türk hukukunun emredici kurallarına aykırı olmayan İslami prensiplerin uyuşmazlığa uygulanması mümkündür. Zira Türk hukukunda anasyonel hukuk kurallarının seçiminin, uygulanacak hukukun emredici hükümlerine aykırı olmamak kaydıyla sözleşme hükmü olarak değerlendirilmesi gerektiği kabul edilmiştir. ${ }^{117}$ Ancak hukuk seçimi klozunda İslam hukuku ya da Şeriatın genel prensipleri gibi belirli bir kalıba sahip olmayan kuralların seçimi taraf iradesini yeterince ortaya koymamaktadır. Bu durumda tarafların iradesinden tereddüt etmeyecek bir belirlilik sağlayacak olan anasyonel kurallar bütününe atıf yapılması daha sağlıklı olacaktır.

Eğer taraflar, uyuşmazlık halinde İslam hukuku/Şeriat prensiplerinin uygulanmasını arzu ediyorlarsa; (a) İslam hukukunun uygulandığı devletlerden birinin hukukunun seçilmesi, (b) AAOIFI gibi yazılı kurallar oluşturan bağımsız kuruluşların kurallarına atıf yapılması, (c)ilgili prensiplerin doğrudan sözleşmede yer alması, seçeneklerinden birini gözetmeleri hukuk seçiminin geçerliliği konusundaki belirsizlikleri ortadan kaldıracaktır. Aksi takdirde hukuk seçimi klozunda sadece "Yüce Şeriat prensipleri”, "İslam’ın genel kuralları" “İslam hukuku” gibi kavramlara yer verilmesi tek başına belirliliği sağlamaya yetmeyecektir. Ancak tarafların gerçek iradesinin tespit edilmesi mümkün ise, uyuşmazlık hakkında İslam dâhil bir dini kurallar bütününe ya da belirli bir mezhebinin ilkelerine göre hüküm kurulması - devlet mahkemesi nezdinde görülen davalarda uygulanacak devlet hukukunun emredici kurallarına aykırı olmamak şartıyla - mümkündür.

\section{KAYNAKÇA}

Abdelhady H, 'Islamic Law in Secular Courts (Again): Teachable Moments from the Journey' (2011) $<$ https://www.opalesque.com/OIFI137/Industry_Snapshot_Islamic__Law_in_Secular_Teachable197. html?act=archiveOIFI\&and=showArticle\&iID=37> Erişim tarihi 17 Nisan 2021.

Abdul-Rahman Y, İslamda Bankacılık ve Finansman (Çev. Salih Tuğ ve Abdullah Tuğ) (İZÜ 2015).

Akgündüz A, Introduction to Islamic Law (OSAV 2010).

Aktepe İE, Faiz ve Finansman Hadisleri (Yedirenk 2010).

Al-Alwani TJ, Source Methodology in Islamic Jurisprudence - Usul al-Fiqh al-Islami (3rd Ed, Londra 2003).

Alsaidi AM, Petroleum Arbitration: Applicable Law and Appropriate Arbitral Forum (A Study of Petroleum Disputes in Arab Countries) (University of London 2004).

117 Türk mahkemeleri nezdinde faize ilişkin emredici kuralların doğrudan uygulanan kurallar kapsamında görülmesi mümkündür. Faize ilişkin 6098 sayılı Türk Borçlar Kanunu dahil çeşitli kanunlarda düzenlemeler bulunmaktadır. TBK m. 88'de akdi faiz, m.120'de temerrüt faizi ve m.253/3'te taksitli satışlarda alıcının temerrüde düşmesi halinde uygulanacak faiz düzenlenmiştir. Kural olarak faiz taraflarca kararlaştırılabilir ancak bunun bir üst sınırı bulunmaktadır. Örneğin TBK m. 88'e göre, "(1)Faiz ödeme borcunda uygulanacak yillık faiz oranı, sözleşmede kararlaştırılmamışsa faiz borcunun doğduğu tarihte yürürlükte olan mevzuat hükümlerine göre belirlenir. (2) Sözleșme ile kararlaştırllacak yıllik faiz oranı, birinci fikra uyarınca belirlenen yıllık faiz oranının yüzde elli fazlasını aşamaz." Faize ilişkin üst sınır kuralları kanımızca doğrudan uygulanan kurallar içerisinde mütalaa edilebilir. 
Amin SH, Islamic Law and Its Implications for the Modern World (Londra 1989).

Ansay Ş, Hukuk Tarihinde İslam Hukuku (3. Bas1, AÜİ 1958).

Armağan S, Anahatlarıyla İslam Hukuku (Işık 2009).

Ayoğlu T, Uluslararası Ticari Sözleşmelere Uygulanan Genel Prensipler, Maddi Hükümler ve Ticari Adet-Teamüller Olarak Lex Mercatoria (2. Bas1, Vedat 2011).

Ayub M, İslami Finansı Anlamak (Çev: Suna Akten Çürük / Raif Parlakkaya) (İktisat 2017).

Balz K, 'Shamil Bank of Bahrain v. Beximco Pharmaceuticals and Others' (2004) 9(1) Yearbook of Islamic and Middle Eastern Law Online 509-526.

Baumeister BM, 'Lex Mercatoria Islamica: Sharia as Choice of Law under Rome I Regulation' Repositorio Universidad Pontificia Comillas <https://repositorio.comillas.edu/xmlui/handle/11531/27196> Erişim tarihi 21 Mart 2021.

Bedir M, 'Fikih to Law: Secularization Through Curriculum' (2004) 11(3) Islamic Law and Society 378-401.

Berman HJ and Kaufman C, 'The Law of International Commercial Transactions (Lex Mercatoria)' (1978) 19(1) Harvard Law Journal 221-277.

Bhatti M, Islamic Law and International Comemrcial Arbitration (Routhledge, 2019).

Blackaby N, Partasides C, Redfern A and Hunter M, Redfern and Hunter on International Arbitration, (5th Ed, OUP 2009).

Çalışkan Y, Uluslararası Satım Hukukunda Kanunlar İhtilafı Meseleleri (Beta 2014).

Casini L, 'The Making of a Lex Sportiva by the Court of Arbitration for Sport, Lex Sportiva:What is Sports Law?' iç Robert Siekmann and Janwillem Soek (edr) Asser International Sport Law Series (Springer 2012) 149171.

Çelikel A ve Erdem B, Bahadır, Milletlerarası Özel Hukuk (16. Bası, Beta 2020).

Chuah J 'Islamic Principles Governing International Trade Financing Instruments: A Study of the Morabaha in English Law' (2006) 27(1) Northwestern Journal of International Law and Business 137-170.

Chukwumerije O, Choice of Law in International Commercial Arbitration (Quorum 1994).

Colon J, 'Choice of Law and Islamic Finance' (2011) 46(2) Texas International Law Journal 410-436.

De Ly, Filip, International Business Law and Lex Mercatoria (Emerald 1992).

Demirkol B, Milletlerarası Özel Hukuk ve Usul Hukuku Hakkında Kanunun 24. Maddesi Çerçevesinde Sözleşmeye Uygulanacak Hukuk (2. Bask1, Vedat 2014).

Dicey AV, Morris JHC, Collins L, Collins, Dicey, Morris and Collins on the Conflict of Laws (15. Bas1, Sweet\&Maxwell 2012).

Doğan V, Milletlerarası Özel Hukuk (6. Bası, Savaş 2020).

Döndüren H, İslam Hukukuna Giriş (Karatay Üniversitesi 2017).

Duval A, 'Lex Sportiva: A Playground for Transnational Law' (2013) 19(6) European Law Journal 822-842.

Colon J, 'Choice of Law and Islamic Finance’ (2011) 46(2) Texas International Law Journal 410-435.

Ercanbrack J, The Transformation of Islamic Law in Global Financial Markets (CambridgeUP 2015).

Erkan M, Milletlerarası Tahkimde Yetki Sorunları (Yetkin 2013).

Fadlallah I, Arbitration Facing Conflicts of Culture: The 2008 Annual School of International Arbitration Lecture' sponsored by Freshfields Bruckhaus Deringer LLP (2009) 25(3) Arbitration International 303318.

Farah AQ, Hattab RM, 'The Application of Sharī Ah Finance Rules in International Commercial Arbitration' (2020) 16(1) Utrecht Law Review 117-139.

Goldman B, The Suez Company an International Company (Le Monde 1956). 
Goldstajn A, 'Usages of Trade and Other Autonomous Rules of International Trade According to the UN (1980) Sales Convention' iç Petar Sarcevic and Paul Volken (edr), International Sale of Goods (Oceana 1986).

Gözler K, 'İslâm Hukukunun Değeri - İslâm Hukuku, Batı Hukukuna Alternatif Olabilir mi?’ (2019) <www. anayasa.gen.tr/islam-hukuku.htm> Erişim tarihi 19 Nisan 2021.

Gümüş M, 'Osmanlı Devleti’nde Kanunlaştırma Hareketleri - İdeolojisi ve Kurumları' (2013) Tarih Okulu (Sayı XIV) 163-200.

Güven K, 'Lex Mercatoria ve Milletlerarası Tahkim' (2014) 34(2) Milletlerarası Özel Hukuk ve Milletlerarası Hukuk Bülteni 1-57.

Hallaq WB, An Introduction to Islamic Law (CambridgeUP 2009).

Junius A, 'Islamic Finance: Issues Surrounding Islamic Law as a Choice of Law under German Conflict of Laws Principles' (2007) 7(2) Chicago Journal of International Law 537-550.

Kalpsüz T, Türkiye’de Milletlerarası Tahkim (2. Bası, Yetkin 2010).

Kamali MH, An Introduction to Shariah (Ilmiah 2006).

Karaca HA, 'CISG’in Milletlerarası Uygulama Alanı, İrade Serbestisi ve Bazı Yorum Meseleleri' (2019) 39(1) Milletlerarası Hukuk ve Milletlerarası Özel Hukuk Bülteni 189-215.

Karaca HA, 'Uluslararası Ticari Sözleşmelerden Kaynaklı Devlet Mahkemelerindeki Yargılamalarda "Hukuk Kuralları”nın Seçimi: Lahey Prensipleri M. 3’iç Sibel Özel ve Mustafa Erkan (edr), Milletlerarası Özel Hukukta Sözleşmesel Meseleler (Oniki Levha 2018).

Kutty F, 'The Sharia Factor in International Commercial Arbitration' (2006) 28(3-4) Loyola of Los Angeles International and Comparative Law Review 565-624.

Mankowski P, 'Article 3 of the Hague Principles: The Final Breakthrough for the Choice of Non-State Law' (2017) 22(2) Uniform Law Review 369-394.

Michaels R, , 'Non-State Law in the Hague Principles on Choice of Law in International Contracts' iç Kai Purnhagen and Peter Rott (edr) Varieties of European Economic Law and Regulation: Liber Amicorum for Hans Micklitsz (Springer 2014).

Nygh P, 'The Reasonable Expectations of the Parties As a Guide to the Choice of Law in Contract and in Tort' iç Collected Courses of the Hague Academy of International Law (Brill 1995) 269-400.

Oğuz A, Lex Mercatoria (Yetkin 2004).

Olatoye KA ve Yekini A, 'Choice of Law As the Governing Law in Islamic Finance Contracts: The United Kingdom and Nigerian Perspectives' (2017) 25(1) IIUM Law Journal 137 - 159.

Ovacı V, 'İslam Hukukunun Karakteristik Özellikleri’ (2015) 7(7) Bozok Üniversitesi İlahiyat Fakültesi Dergisi 69-80.

Ozdem BH, 'The Path of Eastern Arbitration to Take Islamic Finance Disputes from the Hands of English Litigation' (2019) 39(1) Milletlerarası Hukuk ve Milletlerarası Özel Hukuk Bülteni 295-323.

Özdemir Kocasakal H, 'Viyana Konvansiyonu’nun Milletlerarası Özel Hukuk Bakımından Uygulama Alanı' 2013(1) Galatasaray Üniversitesi Hukuk Fakültesi Dergisi 19-52.

Özel S, Akreditif ve Hukuki Niteliği (Beta 1991).

Özel S, Milletlerarası Ticari Tahkimde Kanunlar İhtilafı Meseleleri (Legal 2008).

Permanent Bureau of the Hague Conference on Private Internaitonal Law, Commentary on the Principles on Choice of Law in International Commercial Contracts (the Hague Conference 2015).

Abdulrahman A, 'Shariah as the governing law of Islamic finance contracts in the UK: The impact of Rome I Regulation and the position in arbitration' Young ICCA Forum <https://youngicca-blog.com/2014/11/> Erişim tarihi 4 Mart 2021. 
Şanlı C, Esen E, Ataman Figanmeşe İ, Milletlerarası Özel Hukuk (8. Baskı, Beta 2020).

Şanlı C, Uluslararası Ticari Akitlerin Hazırlanması ve Uyuşmazlıkların Çözüm Yolları (7. Baskı, İstanbul 2019).

Sanson M, Essential International Trade Law (2nd Ed, Australia 2005).

Schmitthoff C, 'International Trade Usages'(ICC 1987) ICC Yayın no. 440/4, Institute of International Business Law and Practice Newsletter.

Selanik AA, Bayram O, Değirmenci IT, 'Viyana Satım Antlaşması’nın (CISG) Tarihsel Gelişimi ve Uygulama Alanı’ (2018) 17(4) Gaziantep Üniversitesi Sosyal Bilimler Dergisi 1353-1367.

Siddiqi MN, Issues in Islamic Banking (IF Londra 1983).

Siddiqui SH, Islamic Banking, (Pakistan 1994).

Süral BC, 'Uluslararası Ticari Sözleşmelere Uygulanacak Hukuk Olarak Unidroit (Özel Hukukun Yeknesaklaştırılması için Uluslararası Enstitü) Prensipleri’ (Doktora Tezi, Dokuz Eylül Üniversitesi 2008).

Şentop M, 'Tanzimat Dönemi Kanunlaştırma Faaliyetleri Literatürü' (2005) 3(5) Türkiye Araştırmaları Literatür Dergisi 647-672.

Tok O ve Akter S, 'Patolojik ve Asimetrik Tahkim Anlaşmalarının Değerlendirilmesi' iç Mustafa Erkan ve Candan Yasan (edr), Tahkim Okulu Paneller Serisi Cilt I (Oniki Levha 2020) 57-101.

United Nations Commission on International Trade Law, UNCITRAL Model Law on International Commercial Arbitration 1985 (With amendments as adopted in 2006).

Von Bar C ve Mankowski P, Internalionales Privatrecht (2. Ed, Beck 2003).

Winship P, 'The Scope of the Vienna Convention on International Sales Contracts' iç Nina M. Galston and Hans Smith (edr), International Sales: The United Nations Convention on Contracts for the International Sale of Goods (New York 1984) 1-53.

Yanpar A, İslami Finans - İlkeler, Araçlar ve Kurumlar (Scala 2014).

Yener Keskin C, Milletlerarası Tahkim Anlaşmasının Kurulması ve Etkisi (Oniki Levha 2017).

Yöney C, 'Sözleşmeye Uygulanacak Hukuk Olarak Lex Sportiva’ iç Sibel Özel ve Hatice Selin Pürselim Arning (edr), Atipik Sözleşmelere Uygulanacak Hukuk (Oniki Levha 2010) 69-115.

Yöney C, 'Viyana Satım Sözleşmesi’nin Tahkim Anlaşmasına Uygulanacak Hukuk Olarak Uygulanabilirliği' (2019) 2 Galatasaray Üniversitesi Hukuk Fakültesi Dergisi 745-781.

Yöney C, Yabancı Hukukun Uygulanması (Oniki Levha 2018).

Zahid A and Mohd Ali H, 'Shari'ah As A Choice Of Law In International Islamic Financial Contracts: Shamil Bank Of Bahrain Case Revisited' (2013) 10(1) US-China Law Review 27-34.

Özbay İ ve Erdem M, 'Bir Kurumsal Tahkim Merkezi Örneği Olarak İslam İşbirliği Teşkilatı Tahkim Merkezi Üzerine Düşünceler' (2020) 2(1) Ankara Sosyal Bilimler Üniversitesi Hukuk Fakültesi Dergisi 1-58.

İsta Blog, 'İslam İşbirliği Teşkilatı Tahkim Merkezi’ (2020) < https://ista.org.tr/blog/haberler/islam-isbirligiteskilati-tahkim-merkezi/> Erişim tarihi 19 Nisan 2021.

Kumtepe Y ve Loschi R, 'Investment Dispute Settlement Body of the Organisation of Islamic Cooperation: A Dead End for Claims under the OIC Investment Agreement?' (2019) Kluwer Arbitration Blog, <http:// arbitrationblog.kluwerarbitration.com/2019/12/29/investment-dispute-settlement-body-of-theorganisation-of-islamic-cooperation-a-dead-end-for-claims-under-the-oic-investment-agreement/> Erişim tarihi 19 Nisan 2021.

\section{Çevrimiçi Kaynaklar}

http://arbitrationblog.kluwerarbitration.com

http://conflictoflaws.net/News/2011/01/PIL-China.pdf. 
http://www.bailii.org/ew/cases/EWCA/Civ/2004/19.html

http://www.kentlaw.edu/perritt/conflicts/rest187.html

https://bahrainbusinesslaws.com/laws/Law-of-Commerce

https://eur-lex.europa.eu/legal-content/en/

https://iccwbo.org/dispute-resolution-services/arbitration/rules-of-arbitration

https://islamansiklopedisi.org.tr/murabaha

https://ista.org.tr/blog/

https://kuran.diyanet.gov.tr/

https://treaties.un.org/

https://www.fedlex.admin.ch/

https://www.izu.edu.tr/docs/

www.anayasa.gen.tr/islam-hukuku.htm

Legalbank Elektronik Hukuk Bankası 